\title{
Exploring the Scope of [Pt2(4-FC6H4)4( $\mu$-SEt2)2] as a Precursor for New Organometallic Platinum(II) and Platinum(IV) Antitumor Agents
}

$†$ Departament de Química Inorgànica, Facultat de Química, Universitat de Barcelona, Diagonal 645, 08028 Barcelona, Spain

¥Institut de Biomedicina (IBUB), Universitat de Barcelona, Barcelona, Spain

$\S$ Laboratori de Química Orgànica, Facultat de Farmàcia, Universitat de Barcelona, Avenida Joan XXIII, $\mathrm{s} / \mathrm{n}, 08028$ Barcelona, Spain

$\perp$ Department of Biochemistry and Molecular Biology, Faculty of Biology, Universitat de Barcelona, and IDIBAPS, Unit Associated with CSIC, Diagonal 643, 08028 Barcelona, Spain

\|Departament de Bioquímica i Biologia Molecular, Facultat de Farmàcia, Avenida Joan XXIII s/n, 08028 Barcelona, Spain

\#Departament de Cristal·lografia, Mineralogia i Dipòsits Minerals, Facultat de Geologia, Universitat de Barcelona, Martí i Franquès s/n, 08028 Barcelona, Spain

$\triangle$ Unitat de Difraccióde Raigs-X, Centre Científic i Tecnològic de la Universitat de Barcelona (CCiTUB), Soléi Sabarís, 1-3, 08028 Barcelona, Spain 
The new compound [Pt2(4-FC6H4)4( $\mu$-SEt2)2] (A) was prepared and fully characterized. The reactions of compound A with ligands $\mathrm{ArCH}=\mathrm{NCH} 2 \mathrm{CH} 2 \mathrm{NMe} 2(\mathrm{Ar}=2-\mathrm{BrC6H} 4,1 \mathrm{a} ; 2,6-\mathrm{Cl} 2 \mathrm{C} 6 \mathrm{H} 3,1 \mathrm{~b}$; 4-

$44 \mathrm{ClC} 6 \mathrm{H} 4,1 \mathrm{c} ; 2-\mathrm{Cl}, 6-\mathrm{FC} 6 \mathrm{H} 3,1 \mathrm{~d})$ were studied under different conditions and produced platinum(II)

45 compounds $[\mathrm{Pt}(4-\mathrm{FC} 6 \mathrm{H} 4) 2(\mathrm{ArCH}=\mathrm{NCH} 2 \mathrm{CH} 2 \mathrm{NMe} 2)](2 \mathrm{~b}-2 \mathrm{~d})$, containing a bidentate $\left[\mathrm{N}^{\prime} \mathrm{N}^{\prime}\right]$ ligand, as

46 well as cyclometalated platinum(IV) or platinum(II) compounds such as $[\mathrm{PtBr}(4-$

47 FC6H4)2(C6H4CH=NCH2CH2NMe2)] (4a) or [ $\mathrm{PtCl}\{(3-\mathrm{FC} 6 \mathrm{H} 3)(2-\mathrm{XC} 6 \mathrm{H} 3) \mathrm{CH}=\mathrm{NCH} 2 \mathrm{CH} 2 \mathrm{NMe} 2\}]$

$48(5 \mathrm{~b}: \mathrm{X}=\mathrm{Cl} ; 5 \mathrm{~d}: \mathrm{X}=\mathrm{F})$, containing a tridentate $\left[\mathrm{C}, \mathrm{N}, \mathrm{N}^{\prime}\right]$ ligand and either a five $(4 \mathrm{a})$ or a seven $(5 \mathrm{~b}, 5 \mathrm{~d})$

49 membered metallacycle. These compounds exhibit a great antiproliferative activity against non-small

50 lung cancer cells (A549), and the best result was obtained for compound $2 \mathrm{c}($ IC50 $=0.3 \pm 0.1 \mu \mathrm{M})$.

51 While compounds 5 alter the mobility of plasmid DNA in a similar way to cisplatin, compound 4 was

52 less efficient in removing the supercoils from DNA. In spite of the very low IC50 value obtained for

53 compound $2 \mathrm{c}$, this compound does not interact with DNA, and it is neither an intercalator nor a

54 topoisomerase I inhibitor.

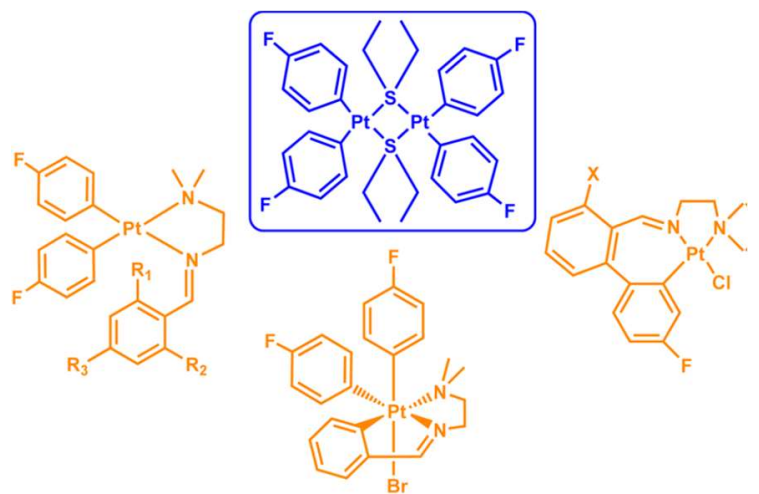


Nowadays platinum(II) complexes (cis-, carbo-, and oxaliplatin) dominate the field of metal-based chemotherapy in worldwide cancer treatment protocols. 1 However, major limitations of these drugs are (i) dose-limiting severe toxicities, (ii) poor bioavailability, and (iii) intrinsic or acquired resistance.2,3 As a consequence, different approaches have emerged to improve the cytotoxic profile of these anticancer platinum compounds.4 Relevant strategies are focused on (i) the stabilization of the Pt(II) ion in the complexes, (ii) the design of Pt(IV) complexes as prodrugs, and (iii) the exploitation of the promising properties associated with organometallic compounds based not only on platinum but also on other metal ions such as palladium, ruthenium, gold, copper, or iron. Cyclometalated platinum(II) complexes containing either bidentate $[\mathrm{C}, \mathrm{N}] 5$ or terdentate $\left[\mathrm{C}, \mathrm{N}, \mathrm{N}^{\prime}\right] 6$ ligands have been recently screened against tumor cells with very promising outcomes. In these compounds, the presence of a $\sigma(\mathrm{Pt}-\mathrm{C})$ bond increases the stability of the complexes, thus allowing them to reach the cell unaltered. Furthermore, the aromatic groups in the cyclometalated ligand might favour intercalative binding to DNA through $\pi-\pi$ stacking, 7 while the labile positions in the coordination sphere of the platinum atom favor covalent coordination to DNA as for cisplatin. Therefore a high cytotoxic activity may result from the combined effect of intercalation and platination operating for cyclometalated platinum compounds.5,6a On the other hand, platinum(IV) complexes, able to produce Pt(II) species by reductive elimination8 or photoactivation, 9 offer several potential advantages. They are stable enough to be administered orally, their stability should result in diminished side effects, and they are amenable to structural modifications via the axial ligands, which can be used to improve their pharmacological properties.

In recent years we have been involved in the use of diarylplatinum(II) complexes as precursors in the synthesis of [C,N,N'] cyclometalated platinum(II) and platinum(IV) compounds 10,11 and the study of the mechanisms involved in these processes.12,13 In particular, along these studies, a novel class of seven-membered platinacycles has been obtained in a reaction involving formation of a Caryl-Caryl bond, and these compounds were shown to display a remarkable antiproliferative activity, even greater than cisplatin, in several human cancer cell lines.6a In order to further explore this area, we undertook a project aimed at the preparation of a new precursor, [Pt2(4-FC6H4)4( $\mu-\mathrm{SEt} 2) 2]$ (A), analogous to compound [Pt2(4-MeC6H4)4( $\mu$-SEt2)2] previously used as metalating agent.11 Binuclear compound A, upon reaction with adequate dinitrogen ligands, should produce new series of organometallic platinum complexes potentially useful as antitumor agents. In addition, the presence of a fluoro substituent in the aryl ligands of compound A should allow an analysis on the importance of the electronic effects in the subsequent reactions. Interestingly, several examples of biologically active platinum fluoroaryl compounds have been previously reported.51-o,14 Moreover, the presence of the NMRactive 19F nucleus will provide an additional spectroscopic handle to characterize the obtained compounds.15,16 An additional interest in this system relies on the fact that fluoro substituents may enhance the binding efficacy and selectivity in pharmaceuticals. 17

The results presented here include the synthesis of the new dimer A, which was found to be an adequate precursor for the synthesis of several organoplatinum compounds such as diarylplatinum(II) compounds containing a bidentate $\left[\mathrm{N}, \mathrm{N}^{\prime}\right]$ ligand $(2 \mathrm{~b}-2 \mathrm{~d})$ and cyclometalated platinum(II) $(5 \mathrm{~b}, 5 \mathrm{~d})$ and platinum(IV) (4a) compounds containing a terdentate $\left[\mathrm{C}, \mathrm{N}, \mathrm{N}^{\prime}\right]$ ligand. Their antiproliferative activity against the A549 human lung cancer cell line has been investigated by means of the MTT colorimetric assay. Additionally, electrophoretic DNA migration studies, in the absence and in the presence of topoisomerase I, have been performed, in order to get further insights into the biological behavior of the synthesized compounds. 
Synthesis and Characterization of Platinum Compounds. Although the synthesis of compound cis108 [Pt(4-FC6H4)2(SMe2)2] has been recently reported,18 our target compound A has not been described so far. The dinuclear compound [Pt2(4-FC6H4)4( $\mu$-SEt2)2] (A) was obtained from the reaction of cis[PtCl2(SEt2)2] with 4-fluorophenyllithium, prepared in situ, and was fully characterized including singlecrystal X-ray diffraction analysis (Figure 1). Suitable crystals of compound A were grown from dichloromethane-methanol at room temperature as the solvate $\mathrm{A} \cdot \mathrm{CH} 2 \mathrm{Cl} 2$. The crystal structure is composed of discrete molecules held together by van der Waals interactions. Both platinum atoms display square-planar coordination geometry, while the sulfur atoms are tetrahedrically bonded to both platinum centers and two ethyl groups. Bond parameters are similar to those found for the analogous compound [Pt2(4-MeC6H4)4( $\mu$-SEt2)2], whose structure has been previously reported.19 In particular, the $\operatorname{Pt}(1) \cdots \operatorname{Pt}(2)$ separation is $3.605 \AA$. The mean planes of the para-fluorophenyl groups form dihedral angles of $85.9(3)^{\circ}, 78.6(3)^{\circ}, 66.3(3)^{\circ}$. and $84.9(3)^{\circ}$ with the Pt2S2 plane.

Ligands $\mathrm{ArCH}=\mathrm{NCH} 2 \mathrm{CH} 2 \mathrm{NMe} 2(\mathrm{Ar}=2-\mathrm{BrC6H} 4,1 \mathrm{a} ; 2,6-\mathrm{Cl} 2 \mathrm{C} 6 \mathrm{H} 3,1 \mathrm{~b} ; 4-\mathrm{ClC} 6 \mathrm{H} 4,1 \mathrm{c} ; 2-\mathrm{Cl}, 6-$ $\mathrm{FC} 6 \mathrm{H} 3,1 \mathrm{~d})$ were selected for this study since the presence of two nitrogen atoms allows formation of a $\left[\mathrm{N}, \mathrm{N}^{\prime}\right]$-chelate upon coordination to platinum and further reaction should produce cyclometalated platinum- (II) or platinum(IV) compounds in agreement with previous studies for similar systems.20 The presence of different substituents in the ortho positions of the aryl $\operatorname{ring}(\mathrm{Br}, \mathrm{Cl}$, or $\mathrm{H})$ is determinant in the reaction pathway and the nature of the final products of such reactions.

The reactions of compound A with ligands $1 \mathrm{a}-1 \mathrm{~d}$ are summarized in Scheme 1. The reaction of [Pt2(4FC6H4)4( $\mu$ - SEt2)2] (A) with imines $1 \mathrm{~b}-1 \mathrm{~d}$ carried out in toluene at room temperature produced compounds of general formula $[\mathrm{Pt}(4-\mathrm{FC} 6 \mathrm{H} 4) 2(\mathrm{ArCH}=\mathrm{NCH} 2 \mathrm{CH} 2 \mathrm{NMe} 2)](2 \mathrm{~b}-2 \mathrm{~d})$. For 1a, the $\mathrm{C}-\mathrm{Br}$ bond in the ortho position is easily activated at room temperature to produce cyclometalated platinum(IV) compound [PtBr(4-FC6H4)2(C6H4CH=NCH2CH2NMe2)] (4a). For this reason, compound 2a was not isolated, although the reaction is expected to proceed through this species in agreement with previous mechanistic studies for related systems. 13 Compounds $2 b-2 d$ were characterized by usual techniques, and in addition, $2 \mathrm{~d}$ was also characterized crystallographically. The $1 \mathrm{H}$ NMR spectra of compounds $2 \mathrm{~b}$ and $2 \mathrm{c}$ display only one group of signals, which was assigned, in agreement with the observed $3 \mathrm{~J}(\mathrm{H}-\mathrm{Pt}$ ) values for the imine hydrogen (ca. $50 \mathrm{~Hz}$ ), to the E isomer. In contrast, compound $2 \mathrm{~d}$ was obtained as a mixture of $\mathrm{Z}$ and $\mathrm{E}$ isomers, as readily deduced from the $1 \mathrm{H}$ and 19F NMR spectra. This result prompted us to monitor by $1 \mathrm{H}$ NMR spectroscopy the stability of compounds $2 \mathrm{~b}$ and $2 \mathrm{c}$ in $\mathrm{CDCl} 3$ solution. While compound $2 \mathrm{c}$ was stable in solution as the $\mathrm{E}$ isomer, compound $2 \mathrm{~b}$ gave after several hours at room temperature a mixture of three compounds, as evidenced by the three resonances observed in the imine region. These were assigned, based on the chemical shifts and the $3 \mathrm{~J}(\mathrm{H}-\mathrm{Pt})$ values, to isomer $\mathrm{E}$ of compound $2 \mathrm{~b}$ initially present, to the $\mathrm{Z}$ isomer $(\delta=8.17 \mathrm{ppm}$, $3 \mathrm{~J}(\mathrm{H}-\mathrm{Pt})=28 \mathrm{~Hz})$, and to the platinum $(\mathrm{IV})$ species $4 \mathrm{~b}(\delta=9.29 \mathrm{ppm}, 3 \mathrm{~J}(\mathrm{H}-\mathrm{Pt})=48 \mathrm{~Hz})$ arising from intramolecular $\mathrm{C}-\mathrm{Cl}$ bond activation. After several days at room temperature, $4 \mathrm{~b}$ was the major component, the ratio $\mathrm{E}: Z$ was $1: 2.2$, and a new peak corresponding to $5 \mathrm{~b}$ was also observed. Formation of the $\mathrm{Z}$ isomer releases the steric congestion by placing the aryl group away from the platinum atom; however, formation of compound $4 \mathrm{~b}$ takes place from the $\mathrm{E}$ isomer. These results support the reaction sequence shown in Scheme 2, in agreement with previously reported mechanisms for analogous systems. 12,13

Suitable crystals of compound $2 \mathrm{~d}$ were grown in dichloromethane-methanol at room temperature. The crystal structure is composed of discrete molecules held together by van der Waals forces. The molecular structure (Figure 2) consists of the E isomer, and bond distances and angles are similar to those reported for analogous compounds. In particular, the angles $\mathrm{CPtC}$ and $\mathrm{CPtN}$ are close to $90^{\circ}$, while the bite angle NPtN is $80.62^{\circ}$. The chelate ring is nearly coplanar with the coordination plane (dihedral 
angle $\left.10.5(2)^{\circ}\right)$, and the parafluorophenyl groups trans to the imine and to the amine are tilted $89.6(3)^{\circ}$ and $64.4(3)^{\circ}$, respectively, to that plane. This arrangement allows for an intramolecular $\pi-\pi$ stacking2 1 between the $\mathrm{C} 7-\mathrm{C} 12$ and the $\mathrm{C} 16-\mathrm{C} 21$ rings, the distance being 3.663(4) $\AA$.

As stated above, the reaction of precursor A with ligand 1a produced a cyclometalated platinum(IV) compound containing a terdentate $\left[\mathrm{C}, \mathrm{N}, \mathrm{N}^{\prime}\right]$ cyclometalated ligand. Compound $4 \mathrm{a}$ was fully characterized including $\mathrm{X}$-ray molecular structure determination of the crystals grown in dichloromethane-methanol. Multinuclear (1H, 19F, 13C, and 195Pt) NMR spectra indicated formation of a single isomer, and bidimensional $1 \mathrm{H}-1 \mathrm{H}$ COSY and NOESY experiments allowed the assignment of all signals observed in the $1 \mathrm{H}$ NMR spectrum. The presence of eight cross-peaks in the aromatic region of the $1 \mathrm{H}-13 \mathrm{C}$ HSQC is also consistent with the proposed structure. All observed coupling constants are in the range expected for monofluorinated aromatic compounds 22 and in good agreement with the values reported for cyclometalated compounds.23 In addition, the chemical shift of the observed signal in the 195Pt NMR spectra $(\delta=-1929.6 \mathrm{ppm})$ is consistent with the presence of a platinum(IV) compound.24

The crystal structure is composed of discrete molecules held together by van der Waals interactions. The molecular structure (Figure 3) confirmed the proposed structure in which the platinum atom displays an octahedral coordination with the three $\mathrm{Pt}-\mathrm{C}$ bonds in a fac arrangement. The $\mathrm{Pt}-\mathrm{C}$ and $\mathrm{Pt}-\mathrm{N}$ distances are in the expected range, and the coordination angles involving the mer-[C,N,N'] are smaller than $90^{\circ}$ $\left(\mathrm{C}(1)-\mathrm{Pt}-\mathrm{N}(1)=81.1(2)^{\circ}\right.$ and $\left.\mathrm{N}(1)-\mathrm{Pt}-\mathrm{N}(2)=78.6(2)^{\circ}\right)$.

As indicated above, the reactions of ligands $1 \mathrm{~b}-1 \mathrm{~d}$ with precursor $\mathrm{A}$ in toluene at room temperature gave compounds $2 \mathrm{~b}-2 \mathrm{~d}$, in which the ligands act as bidentate [N,N'] ligands; further reaction of these compounds was tested in refluxing toluene. As reported for analogous systems, 10,11 compound $2 \mathrm{c}$ is expected to produce under these conditions a five-membered cyclometalated platinum(II) compound, $3 \mathrm{c}$. In the present case, this compound could only be characterized in solution by $1 \mathrm{H}$ and $19 \mathrm{~F}$ NMR spectra, but could not be isolated in a pure form. Residual amounts of the coordination compound $2 \mathrm{c}$ were present after a reaction time of six hours under reflux. Attempts to achieve full conversion of $2 \mathrm{c}$ into $3 \mathrm{c}$ using longer reaction times as well as attempts to purify compound $3 \mathrm{c}$ were unsuccessful and result in decomposition with formation of metallic platinum. Formation of compounds analogous to $3 \mathrm{c}$ has been reported, along with reductive elimination of either benzene or toluene, from complexes such as cis[PtPh2(SMe2)2]10,25 or [Pt2(4-MeC6H4)4( $\mu$-SEt2)2].11 In addition several compounds of general formula [PtAr2L2] $(\mathrm{L}=\mathrm{dmso}$ or SMe2) have been used as metalating agents in the synthesis of cycloplatinated compounds. 26 The failure to obtain pure $3 \mathrm{c}$ could be related to the low nucleophilic character of $\mathrm{A}$ that renders the intramolecular $\mathrm{C}-\mathrm{H}$ bond activation more difficult than for the previously reported precursors. In this sense, it has been previously reported that only intramolecular $\mathrm{C}-\mathrm{Br}$ bond activation, and not $\mathrm{C}-\mathrm{Cl}$ or $\mathrm{C}-\mathrm{H}$ bond activation, took place when cis-[Pt(C6F5)2(SMe2)2] was used as starting material in analogous reactions. 27

When toluene solutions of $2 \mathrm{~b}$ or $2 \mathrm{~d}$ were heated at reflux temperature for six hours, compounds $5 \mathrm{~b}$ and $5 \mathrm{~d}$, depicted in Scheme 1, were obtained as pure solids. These [C,N,N'] cyclometalated platinum(II) compounds containing a sevenmembered metallacycle are formed from the corresponding compounds 2 in a process involving intramolecular $\mathrm{C}-\mathrm{Cl}$ bond activation to produce a platinum(IV) cyclometalated compound, which further reacts to produce compound 5 and eliminates fluorobenzene, as depicted in Scheme 2 for $2 \mathrm{~b}$. Alternatively, compounds 5 could also be obtained in a one-pot procedure after stirring for four hours a toluene mixture of compound $\mathrm{A}$ and the corresponding ligand. Compounds $5 \mathrm{~b}$ and $5 \mathrm{~d}$ were characterized by NMR spectra $(1 \mathrm{H}, 19 \mathrm{~F}$, and $195 \mathrm{Pt})$. The $\delta(195 \mathrm{Pt})$ values are in the range expected for platinum(II) compounds, 24 and in the $1 \mathrm{H}$ NMR spectra the nonequivalence of the protons in both the methyl and the methylene groups indicates that the molecule deviates from planarity. In addition, two-dimensional $1 \mathrm{H}-1 \mathrm{H}$ COSY and NOESY were also carried out for $5 \mathrm{~d}$ in order to achieve a complete assignment. Moreover, a $1 \mathrm{H}-13 \mathrm{C}$ HSQC heterocorrelation evidenced the presence of six cross-peak signals in the aromatic region for $5 \mathrm{~d}$. 
Crystals of $5 \mathrm{~d}$ were grown in dichloromethane-methanol at room temperature. In spite of the disorder NMR spectroscopy. The platinum atom displays an approximately square-planar coordination with a terdentate $\left[\mathrm{C}, \mathrm{N}, \mathrm{N}^{\prime}\right]$ and a chloro ligand. As expected, the seven-membered platinacycle includes a biaryl fragment, and the position of the fluoro substituent (F1) in para position to the newly formed Caryl-Caryl bond and meta to the platinum atom supports the mechanism previously suggested for analogous reactions.13 The process shown in Scheme 3 takes place through reductive coupling of one parafluorobenzene ligand and the aryl ring of the imine ligand to produce a biaryl moiety, which is consequently cyclometalated with elimination of fluorobenzene.

Biological Studies. In this work, a set of compounds with different properties (2b, 2c, 2d, 4a, 5b, and $5 d)$ and the corresponding free ligands $(1 \mathrm{a}-1 \mathrm{~d})$ were evaluated in vitro to assess their activity on the inhibition of A549 human lung cancer cell proliferation, using cisplatin as positive control. Compounds $2 \mathrm{~b}-2 \mathrm{~d}$ are organometallic platinum(II) compounds with one labile position (the dimethylamino fragment), compounds $5 \mathrm{~b}$ and $5 \mathrm{~d}$ are cyclometalated platinum(II) compounds containing two labile positions (both the chloro ligand and the dimethylamino fragment), and compound $4 \mathrm{a}$ is a cyclometalated platinum(IV) compound with a fac-PtC3 arrangement and a meridional [C,N,N'] terdentate ligand, thus leaving one bromide and one aryl ring as axial ligands. Their effect on the growth of the selected cell line was evaluated after $72 \mathrm{~h}$, and the results are displayed in Figure 5. The obtained IC50 values resulting from an average of two experiments are shown in Table 1.

It can be seen from Table 1 that compounds $5 \mathrm{~b}$ and $5 \mathrm{~d}$ exhibit a great antiproliferative activity and lower IC50 values than cisplatin itself. These compounds show little difference in their cytotoxic effectiveness among them and when compared with similar seven-membered platinacycles previously described. 6a Although the presence of fluorine substituents could favour DNA binding, no increase in potency is observed for compounds $5 \mathrm{~b}$ and $5 \mathrm{~d}$, containing fluoro substituents. As previously reported,6a the sevenmembered metallacycles are not planar, the tilt angle between both aryl rings contained in the sevenmembered ring is in the range 50.6-54.2 ${ }^{\circ}$, and consequently, intercalative binding to DNA is not expected. Compounds $2 \mathrm{~b}$ and $2 \mathrm{~d}$ show a notable antiproliferative activity with lower IC50 values than that of cisplatin. With regard to the same standard reference, compound $2 \mathrm{c}$ exhibited a ca. 50 -fold increase in potency. Interestingly compounds $2 b-2 d$ have a very similar structure and only differ in the substitution pattern in the imine aryl group. However, the presence of two substituents in the ortho positions for $2 \mathrm{~b}$ and $2 \mathrm{~d}$ could favor $\mathrm{E}-\mathrm{Z}$ isomerization around the imine bond or even formation of $\mathrm{a}$ platinum(IV) compound as depicted in Scheme 2 for 2b. Complex 2c (without an ortho substituent) turned out to be ca. 20 -fold more active than $2 \mathrm{~b}$ and ca. 40 -fold more active than $2 \mathrm{~d}$.

Most evidence to date indicates that platinum(IV) complexes exhibiting symmetrical axial ligands $(\mathrm{Cl}$, $\mathrm{OH}$, and $\mathrm{OAc}$ ) are reduced under physiological conditions by biologically relevant reducing agents (ascorbic acid, glutathione, metallothionein) to release two axial ligands and yield the cytotoxic platinum(II) species.8a Investigations with a series of three model Pt(IV) complexes with axial chloro, acetato, and hydroxo ligands revealed that they have reduction potentials such that the ease of reduction follows the trend $\mathrm{Cl}>\mathrm{OAc}>\mathrm{OH} .8 \mathrm{j}$ In addition, the difficulty of reduction of $\mathrm{Pt}(\mathrm{IV})$ analogues exhibiting $\mathrm{OH}$-ligands has been correlated with good in vivo biological activity.8k However it was found recently that redox potential does not always correlates with the rate of reduction of the platinum(IV) complexes, and also the precise mechanisms of reduction are not always fully understood.8e,f

On the other hand, there are no structure-activity rules for platinum(IV) complexes per se, except that the platinum(II) congeners used for constructing a platinum(IV) complex must be active.8a Furthermore, to the best of our knowledge, no cytotoxicity has been evaluated so far for [C,N,N']cyclometalated $\mathrm{Pt}(\mathrm{IV})$ complex. Therefore we intended to determine within this project if it is possible that unsymmetrical monomeric Pt(IV) complexes, featuring halide and 4-fluorophenyl as axial ligands, exhibit cytotoxicity versus the cell line selected (A549 human lung cancer). Interestingly the Pt(IV) 
complex 4a synthesized in this study exhibited IC50 values in non-small lung cancer cells (A549) very 252 close to that of the standard reference cisplatin.

253 The effect of binding of the compounds investigated in this study on supercoiled DNA was determined 254 by their ability to alter the electrophoretic mobility of pBluescript plasmid DNA: supercoiled closed circular (ccc) and open circular (oc) forms. Figure 6 shows the electrophoretic mobility of native pBluescript DNA incubated with the synthesized compounds (2b, 2c, 2d, 4a, 5b, and 5d) at increasing amounts ranging from 0 to $200 \mu \mathrm{M}$. To provide a basis for comparison, incubation of DNA with cisplatin and ethidium bromide (EtB) was also performed. As expected, cisplatin greatly altered the electrophoretic mobility of pBluescript DNA at all concentrations tested. At concentrations up to $50 \mu \mathrm{M}$ none of the assayed compounds produced a significant effect on the electrophoretic mobility of native pBluescript DNA. Compounds $5 \mathrm{~b}$ and $5 \mathrm{~d}$ greatly alter the mobility of plasmid DNA at $50 \mu \mathrm{M}$, and at $100 \mu \mathrm{M}$ concentration, the rate of migration of the supercoiled band (ccc) decreases even more and tends to approach that of the nicked relaxed band (oc). Platinum(IV) compound 4a displayed a much lower effect on plasmid DNA mobility, while compounds $2 \mathrm{~b}-2 \mathrm{~d}$ did not modify the DNA migration in spite of their low IC50 values. These results indicated that compounds 5 alter the electrophoretic mobility of pBluescript plasmid DNA and hence interact with DNA like the standard reference, cisplatin. However, compounds 2 and 4 showed a weak effect on DNA electrophoresis, pointing out another mechanism of action or another biomolecular target.

Since compound $2 \mathrm{c}$ was found to be very active (IC50 $=0.3 \mu \mathrm{M}$ ) against A549 lung cancer cells, and $\pi-\pi$ stacking interactions are plausible for these types of compounds, as observed in the crystal structure of compound $2 \mathrm{~d}$, we hypothesized that compounds 2 might behave as intercalating agents. Although intercalation has been traditionally associated with molecules containing fused bi- or tricyclic ring structures, atypical intercalators might be more prevalent than originally thought. 28 In order to ascertain whether compound 2c could be a DNA intercalator, a topoisomerase-based gel assay was performed upon this compound.29,30 Figure 7 shows the electrophoretic mobility of supercoiled DNA treated with topoisomerase I in the presence of compound $2 \mathrm{c}$ at increasing amounts ranging from 10 to $100 \mu \mathrm{M}$. To provide a basis for comparison, unwinding assays with etoposide $(100 \mu \mathrm{M})$ and ethidium bromide $(10$ $\mu \mathrm{M})$ as examples of nonintercalative and intercalative drugs, respectively, were also performed. Results presented in Figure 7 showed that $2 c$ does not prevent unwinding of DNA by the action of topoisomerase I, indicating that this compound is not an intercalator nor an inhibitor of topoisomerase I. 
286 The new compound [Pt2(4-FC6H4)4( $\mu$-SEt2)2] (A) appears to be a suitable precursor for the synthesis

287 of several types of organometallic species such as diarylplatinum(II) compounds containing a bidentate

$288\left[\mathrm{~N}, \mathrm{~N}^{\prime}\right]$ ligand $(2 \mathrm{~b}-2 \mathrm{~d})$ and cyclometalated platinum compounds containing a terdentate $\left[\mathrm{C}, \mathrm{N}, \mathrm{N}^{\prime}\right]$ ligand

289 with either a five-membered platinum(IV) (4a) or a seven-membered platinum(II) (5b-5d) metallacycle.

290 The fluoro substituent in the aryl group remains para to the platinum in coordination compounds 2 and

291 in the cyclometalated platinum(IV) compound 4a. However, for compounds 5 the fluoro group is now

292 para to the formed Caryl-Caryl bond and meta to the platinum center. This result is consistent with a

293 process involving Caryl-Caryl coupling between the carbon atoms bound to platinum of the metalated

294 aryl ring and the para-fluoroaryl ligand, as expected for a biaryl reductive elimination from a

295 platinum(IV) compound. On the other hand, the failure to obtain pure $3 \mathrm{c}$ could be related to the presence

296 of electron-withdrawing fluorosubstituents that reduce the nucleophilic character of compound A

297 compared to previously reported precursors.

298 The new compounds exhibited notable to great antiproliferative activities against the A549 human lung

299 cancer cell line. The behavior of compounds 5 is very similar to that obtained for analogous seven-

300 membered platinacycles, which suggests that the presence of fluoro substituents is not relevant to their biological properties. In spite of the very high potency of compound $2 \mathrm{c}$ (ca. 50-fold greater than the standard reference cisplatin), electrophoretic studies carried out for this compound do not show any evidence of either covalent binding or intercalation with DNA, nor a topoisomerase I inhibitor behavior. The results presented here constitute the first step of current work centered on (i) mechanistic studies for elucidating the mode of action of compounds $2 b-2 d$ and $4 a$ in terms of cell cycle arrest, induction of apoptosis, etc., and (ii) structure-activity relationship analysis upon platinum(IV) complex 4a and structurally related analogues, previously synthesized in our group, in order to elucidate the structural requirements for activity. These studies may provide valuable information for the design of new organometallic compounds with improved potency and pharmacokinetic properties. 
General Procedures. Microanalyses were performed at the Centres Cientifí cs i Tecnolog̀ ics (Universitat de Barcelona). Mass spectra were performed at the Unitat d'Espectrometria de Masses (Universitat de Barcelona) in an LC/MSD-TOF spectrometer using H2O-CH3CN (1:1) to introduce the sample. NMR spectra were performed at the Unitat de RMN d'Alt Camp de la Universitat de Barcelona using a Mercury-400 (1H, $400 \mathrm{MHz}$; 1H-1H COSY; 1H-1H NOESY; 1H-13C HSQC; 13C, 100.6 MHz; 19F, 376.5 MHz) or a Varian VNMRS-400 (195Pt, 85.68 MHz) spectrometer and referenced to SiMe4 (1H, 13C), CFCl3 (19F), or H2PtCl6 in D2O (195Pt). $\delta$ values are given in ppm, and J values in Hz. Abbreviations used: $\mathrm{s}=$ singlet; $\mathrm{d}=$ doublet; $\mathrm{t}=$ triplet; $\mathrm{m}=$ multiplet; $\mathrm{br}=$ broad.

$\mathrm{X}$-ray Diffraction. Suitable crystals were grown in dichloromethane-methanol at room temperature. For 2d, X-ray diffraction data were collected on a Mar 345 diffractometer with image plate detector at $293 \mathrm{~K}$, and the structure was solved by direct methods using the SHELX97 software package and refined by the full-matrix least-squares method with the SHELX97 software package.31 For A, 4a, and 5d X-ray diffraction data were collected on a D8 VENTURE system equipped with a multilayer monochromator and a Mo high brilliance Incoatec Microfocus Source $(\lambda=0.71073 \AA$ ) at $100 \mathrm{~K}$ (A and $5 \mathrm{~d})$ or $90 \mathrm{~K}(4 \mathrm{a})$, and the structures were solved and refined using the Bruker SHELXTL software package.31 For 5d, the compound displays molecular disorder for all atoms except for Pt, C1, and C17, which lie on a mirror plane. CIFs for all four structures and a table of crystallographic data are included in the Supporting Information.

Preparation of the Complexes. Ligands 1a-1d19,32 and compound cis-[PtCl2(SEt2)2]33 were prepared as reported elsewhere. Compound [Pt2(4-FC6H4)4( $\mu$-SEt2)2] (A) was prepared using the following procedure: $3.5 \mathrm{~mL}(37.15 \mathrm{mmol})$ of n-butyllithium in hexane was added under $\mathrm{N} 2$ to $30 \mathrm{~mL}$ of diethyl ether, and the solution was cooled to $0{ }^{\circ} \mathrm{C}$. 4-Fluoroiodobenzene $(1.225 \mathrm{~g} ; 5.52 \mathrm{mmol})$ was slowly added, and the mixture was stirred for $30 \mathrm{~min}$ at $0{ }^{\circ} \mathrm{C}$ After this time, [PtCl2(SEt2)2] (0.502 g; $1.23 \mathrm{mmol}$ ) was added, and the mixture was stirred for $2 \mathrm{~h}$ at room temperature. After cooling to $0{ }^{\circ} \mathrm{C}$, water $(5 \mathrm{~mL})$ was added, the aqueous layer was extracted with dichloromethane $(3 \times 15 \mathrm{~mL})$, and the combined organic layers were dried over magnesium sulfate, filtered, and evaporated to give an oily residue. The solid obtained upon addition of hexane was filtered and dried under vacuum. Yield: $314 \mathrm{mg}$ (53.8\%). 1H NMR (400 MHz, CDCl3): $\delta 7.20$ (dd, 3JH-H = 8.8, 4JH-F = 6.4, 8H, Hortho), 6.72 (dd, $3 \mathrm{JH}-\mathrm{H}=8.8,3 \mathrm{JH}-\mathrm{F}=9.2,8 \mathrm{H}, \mathrm{Hmeta}), 2.51(\mathrm{q}, 3 \mathrm{JH}-\mathrm{H}=7.2,8 \mathrm{H}, \mathrm{CH} 2), 1.82(\mathrm{t}, 3 \mathrm{JH}-\mathrm{H}=7.2,12 \mathrm{H}$, CH3). 19F NMR (376.5 MHz, CDCl3): $\delta-121.6(\mathrm{tt}, 4 \mathrm{JF}-\mathrm{H}=6.4,3 \mathrm{JF}-\mathrm{H}=9.4)$. HRMS-ESI-(+) $\{\mathrm{H} 2 \mathrm{O}-\mathrm{CH} 3 \mathrm{CN}(1: 1)\}: \mathrm{m} / \mathrm{z}$ 968.1805 (calcd for C32H40F4NPt2S2 968.1828) [M + NH4]+. Anal. Found (calcd) for C32H36F4Pt2S2: C: 40.3 (40.4); H: 3.9 (3.8); S: 6.9 (6.7).

Compound [Pt $(4-\mathrm{FC} 6 \mathrm{H} 4) 2\{\mathrm{Me} 2 \mathrm{NCH} 2 \mathrm{CH} 2 \mathrm{~N}=\mathrm{CH}(2,6-\mathrm{Cl} 2 \mathrm{C} 6 \mathrm{H} 3)\}]$ (2b) was obtained after stirring for 4 $\mathrm{h}$ a mixture containing $0.100 \mathrm{~g}(0.105 \mathrm{mmol})$ of cis-[Pt(4-FC6H4)2( $\mu$-SEt2)]2 and $0.055 \mathrm{~g}(0.224 \mathrm{mmol})$ of ligand $1 \mathrm{~b}$ in toluene at room temperature. The solvent was evaporated, and the residue was treated with diethyl ether. The yellow solid was filtered and dried under vacuum. Yield: $106 \mathrm{mg}(80.2 \%) .1 \mathrm{H}$ NMR (400 MHz, CDCl3): $\delta 8.71(\mathrm{~s}, 3 \mathrm{JH}-\mathrm{Pt}=54.4,1 \mathrm{H}, \mathrm{CHN}), 7.26(\mathrm{~m}, 2 \mathrm{H}, \mathrm{Hmeta}), 6.97$ (br s, 3H, HAr), 6.77 (m, 2H, Hmeta), 6.62 (m, 2H, Hortho), 6.14 (m, 2H, Hortho), 4.18 (t, 3JH- $\mathrm{H}=5.6,2 \mathrm{H}$, $\mathrm{CH} 2), 2.81(\mathrm{t}, 3 \mathrm{JH}-\mathrm{H}=5.6,2 \mathrm{H}, \mathrm{CH} 2), 2.60(\mathrm{~s}, 3 \mathrm{JH}-\mathrm{Pt}=18.8,6 \mathrm{H}, \mathrm{NMe} 2) .19 \mathrm{~F} \mathrm{NMR}(376.5 \mathrm{MHz}$, CDCl3): $\delta-126.7$ (m, 1F), -124.9 (m, 1F). HRMS-ESI- $(+)\{$ H2O-CH3CN $(1: 1)\}: \mathrm{m} / \mathrm{z} 534.0475$ (calcd for C17H18Cl2FN2Pt 535.0473) [M - C6H4F]+; 652.0697 (calcd for C23H22C12F2N2NaPt 652,0668) $[\mathrm{M}+\mathrm{Na}]+; 1276.1858$ (calcd for C46H48Cl4F4N5Pt2 1276.1890) [2M + NH4]+. Anal. Found (calcd for $\mathrm{C} 23 \mathrm{H} 22 \mathrm{Cl} 2 \mathrm{~F} 2 \mathrm{~N} 2 \mathrm{Pt}$ ): C: 44.0 (43.8); H: $3.6(3.5) ; \mathrm{N}: 4.2(4.4)$.

Compound [Pt(4-FC6H4)2 $\{\mathrm{Me} 2 \mathrm{NCH} 2 \mathrm{CH} 2 \mathrm{~N} \bigoplus \mathrm{CH}(4-\mathrm{ClC} 6 \mathrm{H} 4)\}]$ (2c) was obtained using the same procedure from 1c. Yield: $108 \mathrm{mg}(86.4 \%)$. 
NMR labeling for $2 \mathrm{c}$ :

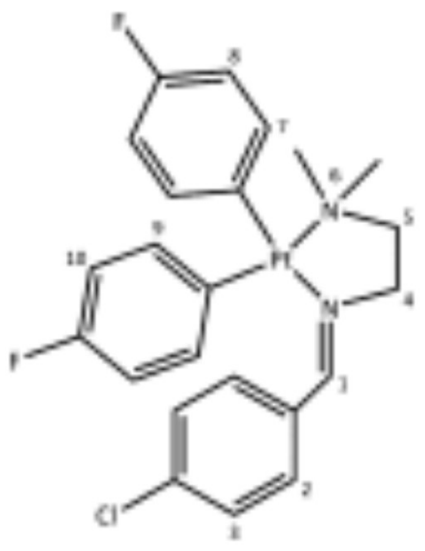

366

367

368

369

370

371

372

373

374

375

376

377

378

379

380

381

382

383

384

385

386

387

388

389

390

391

392

393

394

395

396

397

398

399

400

401

402

403

404
1H NMR (400 MHz, CD3COCD3): $\delta 9.11(\mathrm{~s}, 3 \mathrm{JH}-\mathrm{Pt}=47.2,1 \mathrm{H}, \mathrm{H} 1), 8.20(\mathrm{~d}, 3 \mathrm{JH}-\mathrm{H}=8.8,2 \mathrm{H}, \mathrm{H} 2)$, $7.38(\mathrm{dd}, 3 \mathrm{JH}-\mathrm{H}=8.4,4 \mathrm{JH}-\mathrm{F}=6.8,2 \mathrm{H}, \mathrm{H} 7), 7.09(\mathrm{~d}, 3 \mathrm{JH}-\mathrm{H}=8.4,2 \mathrm{H}, \mathrm{H} 3), 6.84(\mathrm{dd}, 3 \mathrm{JH}-\mathrm{H}=8.8$, $4 \mathrm{JH}-\mathrm{F}=6.8,2 \mathrm{H}, \mathrm{H} 9), 6.67(\mathrm{dd}, 3 \mathrm{JH}-\mathrm{H}=8.8,4 \mathrm{JH}-\mathrm{F}=10,2 \mathrm{H}, \mathrm{H} 8), 6.13(\mathrm{dd}, 3 \mathrm{JH}-\mathrm{H}=8.8,3 \mathrm{JH}-\mathrm{F}=$ $10,2 \mathrm{H}, \mathrm{H} 10), 4.36(\mathrm{t}, 3 \mathrm{JH}-\mathrm{H}=5.6,2 \mathrm{H}, \mathrm{H} 4), 2.96(\mathrm{t}, 3 \mathrm{JH}-\mathrm{H}=5.6,2 \mathrm{H}, \mathrm{H} 5), 2.67(\mathrm{~s}, 3 \mathrm{JH}-\mathrm{Pt}=21.2$, 6H, H6). 19F NMR (376.5 MHz, CD3COCD3): $\delta-126.9$ (tt, 3JF-H $=10.2,4 J F-H=6.8,1 \mathrm{~F}),-126.1$ $(\mathrm{tt}, 3 \mathrm{JF}-\mathrm{H}=10.2,4 \mathrm{JF}-\mathrm{H}=6.8,1 \mathrm{~F}) .195 \mathrm{Pt}$ NMR $(85.68 \mathrm{MHz}, \mathrm{CDCl} 3): \delta-3388.6$ (s). HRMS-ESI-(+) $\{\mathrm{H} 2 \mathrm{O}-\mathrm{CH} 3 \mathrm{CN}(1: 1)\}: \mathrm{m} / \mathrm{z} 404.0473$ (calcd for C11H14ClN2Pt 404.0487) [M - 2FC6H4 - H]+; 613.1484 (calcd for C23H27ClF2N3Pt 613.1503) [M + NH4]+; 1208.2616 (calcd for C46H50Cl2F4N5Pt2 1208.2669) [2M + NH4]+. Anal. Found (calcd for C23H23ClF2N2Pt $\cdot \mathrm{C} 4 \mathrm{H} 10 \mathrm{O}$ ): C: 48.5 (48.4); H: 4.6 (5.0); N: 4.3 (4.2).

Compound [Pt(4-FC6H4)2 $\{\mathrm{Me} 2 \mathrm{NCH} 2 \mathrm{CH} 2 \mathrm{~N} \bigoplus \mathrm{CH}(2-\mathrm{Cl}-6-\mathrm{FC} 6 \mathrm{H} 3)\}]$ (2d) was obtained using the same procedure from 1d. Yield: $107 \mathrm{mg}(82.9 \%)$. $1 \mathrm{H} \mathrm{NMR}(400 \mathrm{MHz}, \mathrm{CD} 3 \mathrm{COCD} 3): \delta 8.74(\mathrm{~s}, 3 \mathrm{JH}-\mathrm{Pt}=$ 55.6, $1 \mathrm{H}, \mathrm{CHN}, \mathrm{E}$ isomer), $8.27(\mathrm{~s}, 3 \mathrm{JH}-\mathrm{Pt}=26.0,1 \mathrm{H}, \mathrm{CHN}, \mathrm{Z}$ isomer), $7.43(\mathrm{~m}, 2 \mathrm{H}), 7.34(\mathrm{t}, 3 \mathrm{JH}-\mathrm{H}=$ 8.0, 4H), 7.08-7.02 (m, 2H), $6.87(\mathrm{~m}, 2 \mathrm{H}), 6.78-6.71(\mathrm{~m}, 10 \mathrm{H}), 6.14(\mathrm{dd}, 3 \mathrm{JH}-\mathrm{F}=12.0,3 \mathrm{JH}-\mathrm{H}=8.0$, 2H), 4.20 (m, 4H, CH2), $2.81(\mathrm{t}, 3 \mathrm{JH}-\mathrm{H}=8.0,2 \mathrm{H}, \mathrm{CH} 2), 2.78(\mathrm{t}, 3 \mathrm{JH}-\mathrm{H}=8.0,2 \mathrm{H}, \mathrm{CH} 2), 2.62(\mathrm{~s}, 6 \mathrm{H}$, NMe2), 2.61 (s, 6H, NMe2). 19F NMR (376.5 MHz, CD3COCD3): $\delta-126.5$ (tt, 3JH-F $=10.2,4 \mathrm{JH}-\mathrm{F}$ $=7.2,1 \mathrm{~F}),-124.8(\mathrm{tt}, 3 \mathrm{JH}-\mathrm{F}=10.2,4 \mathrm{JH}-\mathrm{F}=6.8,1 \mathrm{~F}),-124.5(\mathrm{tt}, 3 \mathrm{JH}-\mathrm{F}=10.2,4 \mathrm{JH}-\mathrm{F}=7.2,1 \mathrm{~F})$, $-124.2(\mathrm{tt}, 3 \mathrm{JH}-\mathrm{F}=10.2,4 \mathrm{JH}-\mathrm{F}=6.8,1 \mathrm{~F}),-108.5(\mathrm{dd}, 3 \mathrm{JH}-\mathrm{F}=9.0,4 \mathrm{JH}-\mathrm{F}=6.0,1 \mathrm{~F}),-107.5(\mathrm{dd}$, $3 \mathrm{JH}-\mathrm{F}=8.6,4 \mathrm{JH}-\mathrm{F}=6.0 \mathrm{~Hz}, 1 \mathrm{~F}) .195 \mathrm{Pt} \mathrm{NMR}(85.68 \mathrm{MHz}, \mathrm{CDCl}): \delta(\mathrm{ppm})-3359.0(\mathrm{~s})$. HRMSESI-(+) $\{\mathrm{H} 2 \mathrm{O}-\mathrm{CH} 3 \mathrm{CN}(1: 1)\}: \mathrm{m} / \mathrm{z} 518.0774$ (calcd for C17H18ClF2N2Pt 518.0768) [M - FC6H4]+; 614.1133 (calcd for C23H23ClF3N2Pt 614.1146) $[\mathrm{M}+\mathrm{H}]+$. Anal. Found (calcd for C23H22ClF3N2Pt): C: 45.3 (45.0); H: 4.0 (3.6); N: 4.3 (4.6).

Compound [PtBr(4-FC6H4)2 $\{\mathrm{Me} 2 \mathrm{NCH} 2 \mathrm{CH} 2 \mathrm{~N} \bigoplus \mathrm{CHC} 6 \mathrm{H} 4\}]$ (4a) was obtained as a white solid following the same procedure as for compounds $2 \mathrm{~b}-2 \mathrm{~d}$ from $0.100 \mathrm{~g}(0.105 \mathrm{mmol})$ of cis-[Pt(4FC6H4)2( $\mu$-SEt2)]2 and $0.054 \mathrm{~g}(0.212 \mathrm{mmol})$ of ligand 1a for $4 \mathrm{~h}$. Yield: $77.5 \mathrm{mg}(57.8 \%)$. 
NMR labeling for 4a:

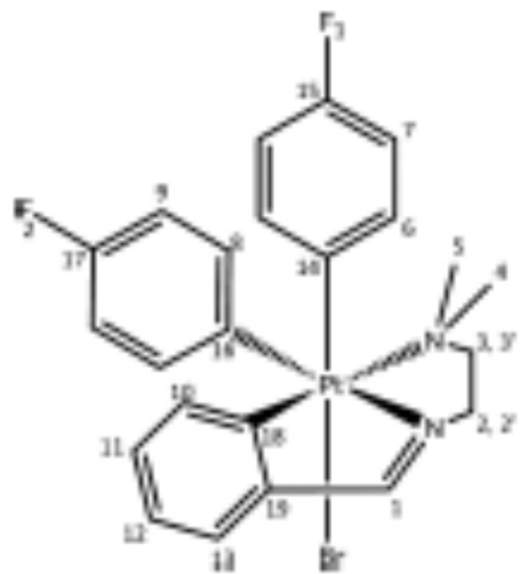

1H NMR (400 MHz, CD3COCD3): $\delta 8.95(\mathrm{~s}, 3 \mathrm{JH}-\mathrm{Pt}=47.6,1 \mathrm{H}, \mathrm{H} 1), 7.69(\mathrm{t}, 3 \mathrm{JH}-\mathrm{Pt}=32.0,3 \mathrm{JH}-\mathrm{H}=$ $4 \mathrm{JH}-\mathrm{F}=6.8,2 \mathrm{H}, \mathrm{H} 8), 7.51(\mathrm{~d}, 3 \mathrm{JH}-\mathrm{H}=6.8,1 \mathrm{H}, \mathrm{H} 13), 7.21(\mathrm{~d}, 3 \mathrm{JH}-\mathrm{H}=7.6,1 \mathrm{H}, \mathrm{H} 10), 7.15(\mathrm{t}, 3 \mathrm{JH}-\mathrm{H}$ $=6.8,1 \mathrm{H}, \mathrm{H} 11), 7.05(\mathrm{t}, 3 \mathrm{JH}-\mathrm{H}=6.8,1 \mathrm{H}, \mathrm{H} 12), 6.88(\mathrm{dd}, 3 \mathrm{JH}-\mathrm{Pt}=52.0,3 \mathrm{JH}-\mathrm{H}=8.0,4 \mathrm{JH}-\mathrm{F}=6.0$, $2 \mathrm{H}, \mathrm{H6}), 6.88(\mathrm{t}, 3 \mathrm{JH}-\mathrm{F}=3 \mathrm{JH}-\mathrm{H}=8.7,2 \mathrm{H}, \mathrm{H} 7), 6.62(\mathrm{~m}, 2 \mathrm{H}, \mathrm{H} 9), 4.70(\mathrm{~m}, 1 \mathrm{H}, \mathrm{H} 2), 4.45$ (m, 2H, H3', $\left.\mathrm{H} 2^{\prime}\right), 3.08(\mathrm{~m}, 1 \mathrm{H}, \mathrm{H} 3), 2.93(\mathrm{~s}, 3 \mathrm{JH}-\mathrm{Pt}=11.2,3 \mathrm{H}, \mathrm{H} 4), 2.64(\mathrm{~s}, 3 \mathrm{JH}-\mathrm{Pt}=15.2,3 \mathrm{H}, \mathrm{H} 5) .19 \mathrm{~F}$ NMR (376.5 MHz, CD3COCD3): $\delta-123.2(\mathrm{tt}, 5 \mathrm{JF}-\mathrm{Pt}=12.8,3 \mathrm{JF}-\mathrm{H}=9.0,4 \mathrm{JF}-\mathrm{H}=6.0,1 \mathrm{~F}, \mathrm{~F} 2),-122.4(\mathrm{tt}$, $5 \mathrm{JF}-\mathrm{Pt}=18.8,3 \mathrm{JF}-\mathrm{H}=9.4,4 \mathrm{JF}-\mathrm{H}=6.0,1 \mathrm{~F}, \mathrm{~F} 1) .13 \mathrm{C} \mathrm{NMR}(100 \mathrm{MHz}, \mathrm{CD} 3 \mathrm{COCD} 3): \delta 171.9(\mathrm{C} 1)$, $161.7,147.3,139.0(\mathrm{~d}, 4 \mathrm{JH}-\mathrm{F}=5.0, \mathrm{C} 8), 135.5(\mathrm{~d}, 3 \mathrm{JC}-\mathrm{F}=6.4, \mathrm{C} 6), 134.86,131.75,131.6(\mathrm{C} 10)$, 131.5 (C11), 129.9 (C13), 128.8, 128.1, $124.1(\mathrm{C} 12), 113.1(\mathrm{~d}, 2 \mathrm{JC}-\mathrm{F}=19.6, \mathrm{C} 7), 112.9(\mathrm{~d}, 2 \mathrm{JC}-\mathrm{F}=$ 19.1, C9), 66.0 (C2), 52.6 (C3), 50.0 (C4), 47.9 (C5). 195Pt NMR (85.68 MHz, CDCl3): $\delta-1929.6$ (s). HRMS-ESI-(+) $\{\mathrm{H} 2 \mathrm{O}-\mathrm{CH} 3 \mathrm{CN}(1: 1)\}: \mathrm{m} / \mathrm{z} 464.1092$ (calcd for C17H1 8FN2Pt 464.1096) [M - FC6H4 $-\mathrm{H}-\mathrm{Br}$ ]+; 544.0354 (calcd for C17H19BrFN2Pt 544.0357) [M - FC6H4]+; 560.1469 (calcd for C23H23F2N2Pt 560.1471) [M - Br]+; 657.1006 (calcd for C23H27BrF2N3Pt 657.0998) [M + NH4]+; 1199.2099 (calcd for C46H46BrF4N4Pt2 1199.2132) [2M - Br]+; 1279.1362 (calcd for C46H47Br2F4N4Pt2 1279.1393) [2M + H]+. Anal. Found (calcd for C23H23BrF2N2Pt): C: 43.2 (43.2); H: 3.8 (3.6); N: 4.4 (4.4).

Compound $[\mathrm{PtCl}\{(3-\mathrm{FC} 6 \mathrm{H} 3)(2-\mathrm{ClC} 6 \mathrm{H} 3) \mathrm{CH} \bigoplus \mathrm{NCH} 2 \mathrm{CH} 2 \mathrm{NMe} 2\}](5 \mathrm{~b})$ was obtained after stirring under reflux for $6 \mathrm{~h}$ a solution containing $0.075 \mathrm{~g}(0.119 \mathrm{mmol})$ of compound $2 \mathrm{~b}$. The solvent was evaporated, and the residue was treated with diethyl ether. The yellow solid was filtered and dried under vacuum. Yield: $29 \mathrm{mg}(45.9 \%)$.

NMR labeling for $5 \mathrm{~b}$ :

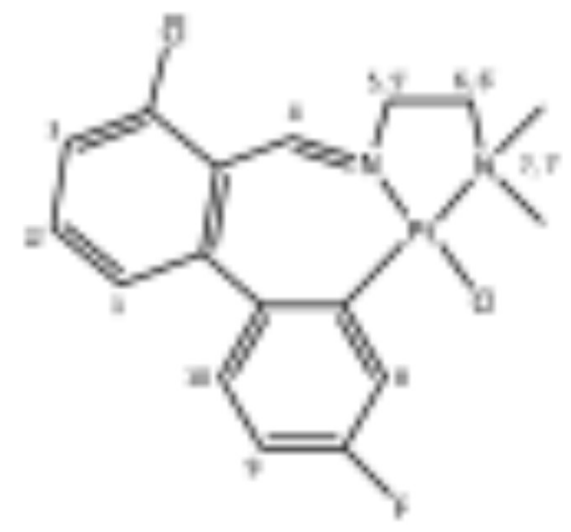


1H NMR (400 MHz, CDCl3): $\delta 9.24(\mathrm{~s}, 3 \mathrm{JH}-\mathrm{Pt}=144.0,1 \mathrm{H}, \mathrm{H} 4), 7.51(\mathrm{t}, 3 \mathrm{JH}-\mathrm{H}=7.6,1 \mathrm{H}, \mathrm{H} 2), 7.38$ (m, 1H, H8), 7.31 (d, 3JH-H = 7.6, 2H, H1,3), $6.92(\mathrm{~m}, 1 \mathrm{H}, \mathrm{H} 9), 6.70(\mathrm{~m}, 1 \mathrm{H}, \mathrm{H} 10), 4.52(\mathrm{~m}, 1 \mathrm{H}, \mathrm{H} 5)$, $3.98\left(\mathrm{~d}, 2 \mathrm{JH}-\mathrm{H}=10.8,1 \mathrm{H}, \mathrm{H} 5^{\prime}\right), 3.01$ (s, 3H, H7), 2.73 (m, 4H, H7',6'), 2,61 (m, 1H, H6). 19F NMR (376.5 MHz, CDCl3): $\delta(\mathrm{ppm})-116.6$ (ddd, 3JF- $\mathrm{H}=10.5,3 \mathrm{JF}-\mathrm{H}=7.9,4 \mathrm{JF}-\mathrm{H}=6.0)$. 195Pt NMR (85.68 MHz, CDCl3): $\delta-3075.1$ (s). HRMS-ESI- $(+)\{\mathrm{H} 2 \mathrm{O}-\mathrm{CH} 3 \mathrm{CN}(1: 1)\}: \mathrm{m} / \mathrm{z} 534.0466$ (calcd for C17H18Cl2FN2Pt 534.0473) [M + H]+; 551.0734 (calcd for C17H21Cl2FN3Pt 551.0738) [M + NH4]+; 1084.1108 (calcd for C34H38Cl4F2N5Pt2 1084.1139) [2M + NH4]+. Anal. Found (calcd for C17H17Cl2FN2Pt): C: 37.9 (38.2); H: $3.2(3.2) ; \mathrm{N}: 4.8$ (5.2).

Compound $[\mathrm{PtCl}\{(3-\mathrm{FC} 6 \mathrm{H} 3)(2-\mathrm{FC} 6 \mathrm{H} 3) \mathrm{CH}=\mathrm{NCH} 2 \mathrm{CH} 2 \mathrm{NMe} 2\}](5 \mathrm{~d})$ was prepared using the same procedure from $2 \mathrm{~d}$. Alternatively, $5 \mathrm{~d}$ was prepared as a yellow solid from $0.150 \mathrm{~g}(0.158 \mathrm{mmol})$ of compound cis-[Pt(4-FC6H4)2( $\mu$-SEt2)]2 and $0.074 \mathrm{~g}(0.324 \mathrm{mmol})$ of ligand $1 \mathrm{~d}$ in toluene with continuous stirring at room temperature for $4 \mathrm{~h}$ followed by heating under reflux for $6 \mathrm{~h}$. The reaction mixture was evaporated, and the yellow oily residue was treated with dichloromethane- methanol. After cooling the mixture, a solid was produced, filtered, and dried under vacuum. Yield: $124 \mathrm{mg}$ (75.9\%). NMR labeling for 5d:

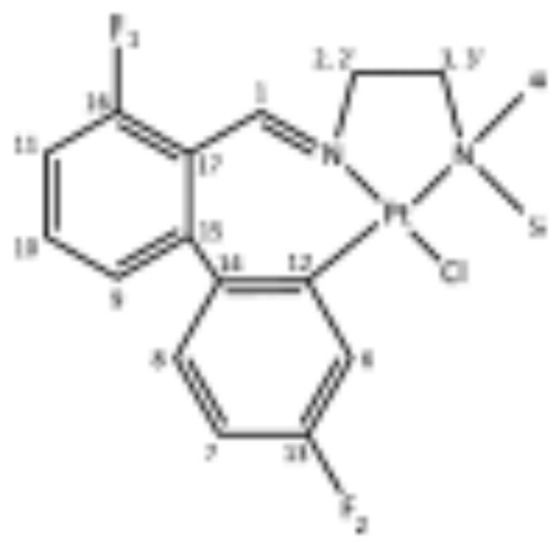

H NMR (400 MHz, CD3COCD3): $\delta 9.38(\mathrm{~s}, 3 \mathrm{JH}-\mathrm{Pt}=144.4,1 \mathrm{H}, \mathrm{H1}), 7.69(\mathrm{td}, 3 \mathrm{JH}-\mathrm{H}=8.0,4 \mathrm{JH}-\mathrm{F}=$ $6.0,1 \mathrm{H}, \mathrm{H} 10), 7,27$ (dd, 3JH-F = 10.8, 4JH-H = 2.8, 1H, H6), $7.21(\mathrm{~d}, 3 \mathrm{JH}-\mathrm{H}=8.0,1 \mathrm{H}, \mathrm{H} 9), 7.20$ $(\mathrm{ddd}, 3 \mathrm{JH}-\mathrm{F}=12.0,3 \mathrm{JH}-\mathrm{H}=8.0,4 \mathrm{JH}-\mathrm{H}=0.8,1 \mathrm{H}, \mathrm{H} 11), 6.94(\mathrm{dd}, 3 \mathrm{JH}-\mathrm{H}=8.4,4 \mathrm{JH}-\mathrm{F}=6.0,1 \mathrm{H}$, $\mathrm{H} 8), 6.65(\mathrm{td}, 3 \mathrm{JH}-\mathrm{H}=3 \mathrm{JH}-\mathrm{F}=8.4,4 \mathrm{JH}-\mathrm{H}=2.8,1 \mathrm{H}, \mathrm{H} 7), 4.56(\mathrm{dtd}, 2 \mathrm{JH}-\mathrm{H}=12.8,3 \mathrm{JH}-\mathrm{H}=3 \mathrm{JH}-\mathrm{H}$ $=4.4,4 \mathrm{JH}-\mathrm{H}=1.2,1 \mathrm{H}, \mathrm{H} 2), 4.31$ (ddd, $2 \mathrm{JH}-\mathrm{H}=11.6,3 \mathrm{JH}-\mathrm{H}=3.6,3 \mathrm{JH}-\mathrm{H}=0.4,1 \mathrm{H}, \mathrm{H} 2$ '), 2.99 (s, $3 \mathrm{H}, \mathrm{H} 5), 2.85$ (m, 2H, H3, H3'), 2.65 (s, 3H, H4). 19F NMR (376.5 MHz, CD3COCD3): $\delta-120.0$ (ddd, $3 \mathrm{JF}-\mathrm{H}=11.3,3 \mathrm{JF}-\mathrm{H}=8.7,4 \mathrm{JF}-\mathrm{H}=6.4,1 \mathrm{~F}, \mathrm{~F} 2),-118,3$ (ddd, $3 \mathrm{JF}-\mathrm{H}=10.2,4 \mathrm{JF}-\mathrm{H}=6.0,5 \mathrm{JF}-\mathrm{H}=$ 2.3, 1F, F1). 13C NMR (100 MHz, CD3COCD3): $\delta 159.8(\mathrm{C} 1), 133.1(\mathrm{~d}, 3 \mathrm{JC}-\mathrm{F}=10.4, \mathrm{C} 10), 130.1(\mathrm{~d}$, $3 \mathrm{JC}-\mathrm{F}=8.2, \mathrm{C} 8), 128.8(\mathrm{~d}, 4 \mathrm{JC}-\mathrm{F}=2.8, \mathrm{C} 9), 125.8(\mathrm{~d}, 2 \mathrm{JC}-\mathrm{F}=17.5, \mathrm{C} 6), 112.9(\mathrm{~d}, 2 \mathrm{JC}-\mathrm{F}=22.2$, C11), 109.4 (d, 2JC-F = 23.0, C7), $67.4(\mathrm{C} 2), 64.8$ (C3), 50.1 (C4), 47.2 (C5). 195Pt NMR (85.68 MHz, CD3COCD3): $\delta-3259.0$ (s). HRMS-ESI-(+) $\{\mathrm{H} 2 \mathrm{O}-\mathrm{CH} 3 \mathrm{CN}(1: 1)\}: \mathrm{m} / \mathrm{z} 518.0759$ (calcd for C17H18ClF2N2Pt 518.0768) [M + H]+; 535.1006 (calcd for C17H21ClF2N3Pt 535.1034) [M + $\mathrm{NH} 4]+; 1052.1709$ (calcd for C34H38Cl2F4N5Pt2 1052.1730) [2M + NH4]+. Anal. Found (calcd for C17H17ClF2N2Pt): C: 39.7 (39.4); H: 3.4 (3.3); N: 5.3 (5.4).

Compound $[\mathrm{Pt}\{(4-\mathrm{FC} 6 \mathrm{H} 4)\{\mathrm{Me} 2 \mathrm{NCH} 2 \mathrm{CH} 2 \mathrm{~N} \bigoplus \mathrm{CH}(3-\mathrm{ClC} 6 \mathrm{H} 3)\}]$ (3c) was obtained as an impure solid from $0.150 \mathrm{~g}(0.158 \mathrm{mmol})$ of compound cis-[Pt(4-FC6H4)2( $\mu$-SEt2)]2 and $0.066 \mathrm{~g}(0.313 \mathrm{mmol})$ of ligand $1 \mathrm{c}$ in toluene with continuous stirring at room temperature for $4 \mathrm{~h}$ followed by heating under reflux for $6 \mathrm{~h}$. The reaction mixture was evaporated, and the yellow oily residue was treated with dichloromethane- methanol. After cooling the mixture, a solid was produced, filtered, and dried under vacuum. Analogous results were obtained when $2 \mathrm{c}$ was refluxed in toluene for $6 \mathrm{~h}$. $1 \mathrm{H} \mathrm{NMR}(400 \mathrm{MHz}$, $\mathrm{CDCl} 3): \delta 8.38(\mathrm{~s}, 3 \mathrm{JH}-\mathrm{Pt}=57.2, \mathrm{CHN}), 3.97(\mathrm{t}, 3 \mathrm{JH}-\mathrm{H}=4.0,2 \mathrm{H}, \mathrm{CH} 2), 3.12(\mathrm{t}, 3 \mathrm{JH}-\mathrm{H}=4.0,2 \mathrm{H}$, $\mathrm{CH} 2), 2.67(\mathrm{~s}, 3 \mathrm{JH}-\mathrm{Pt}=20.0,6 \mathrm{H}, \mathrm{NMe} 2) .19 \mathrm{~F} \mathrm{NMR}(376.5 \mathrm{MHz}, \mathrm{CDCl} 3): \delta(\mathrm{ppm})-123.4(\mathrm{tt}, 3 \mathrm{JF}-\mathrm{H}$ $=10.2,4 \mathrm{JF}-\mathrm{H}=6.8,1 \mathrm{~F})$. 
Biological Studies. Cell Culture. Human lung carcinoma A549 cells were grown as a monolayer culture in minimum essential medium (DMEM with L-glutamine, without glucose and without sodium pyruvate) in the presence of $10 \%$ heat-inactivated fetal calf serum, $10 \mathrm{mM}$ D-glucose, and $0.1 \%$ streptomycin/penicillin, in standard culture conditions (humidified air with $5 \% \mathrm{CO} 2$ at $37^{\circ} \mathrm{C}$ ). Cell Viability Assay. For A549 cell viability assays, compounds were suspended in DMSO at $20 \mathrm{mM}$ as stock solution. To obtain final assay concentrations, they were diluted in DMEM (final concentration of DMSO was the same for all final dilutions and always lower than 1\%). The assay was performed by a variation of the MTT assay described by Mosmann et al.34 as specified by Matito and co-workers, 35 which is based on the ability of live cells to cleave the tetrazolium ring of the MTT, thus producing formazan, which absorbs at $550 \mathrm{~nm}$. In brief, $2.5 \times 103$ A549 cells/well were cultured in 96-well plates for $24 \mathrm{~h}$ prior to the addition of different compounds at different concentrations, in triplicate. After further incubation for $72 \mathrm{~h}$, the supernatant was aspirated, and $100 \mu \mathrm{L}$ of filtered MTT $(0.5 \mathrm{mg} / \mathrm{mL})$ was added to each well. Following $1 \mathrm{~h}$ of incubation with the MTT, the supernatant was removed, and the precipitated formazan was dissolved in $100 \mathrm{Ml}$ of DMSO. Relative cell viability, compared to the viability of untreated cells, was measured by absorbance at $550 \mathrm{~nm}$ on an ELISA plate reader (Tecan Sunrise MR20-301, TECAN, Salzburg, Austria). Concentrations that inhibited cell growth by $50 \%$ (IC50) after $72 \mathrm{~h}$ of treatment were subsequently calculated.

DNA Migration Studies. Compounds were dissolved in high-purity DMSO at $10 \mathrm{mM}$ as stock solution. Then, serial dilutions were made in Milli-Q water (1:1). Plasmid pBluescript SK+ (Stratagene) was obtained using QIAGEN plasmid midi kit as described by the manufacturer. Interaction of drugs with pBluescript SK + plasmid DNA was analyzed by agarose gel electrophoresis following a modification of the method described by Abdullah et al.36 In brief, plasmid DNA aliquots $(40 \mu \mathrm{g} \mathrm{mL}-1)$ were incubated in TE buffer (10 mM Tris-HCl, $1 \mathrm{mM}$ EDTA, $\mathrm{pH}$ 7.5) with different concentrations of the compounds (ranging from 0 to $200 \mu \mathrm{M}$ ) at $37^{\circ} \mathrm{C}$ for $24 \mathrm{~h}$. Final DMSO concentration in the reactions was always lower than $1 \%$. For comparison, cisplatin and ethidium bromide were used as controls. Aliquots of 20 $\mu \mathrm{L}$ of compound-DNA complexes containing $0.8 \mu \mathrm{g}$ of DNA were subjected to $1 \%$ agarose gel electrophoresis in TAE buffer ( $40 \mathrm{mM}$ Tris-acetate, $2 \mathrm{mM}$ EDTA, $\mathrm{pH}$ 8.0). The gel was stained in the same buffer containing ethidium bromide $(0.5 \mathrm{mg} \mathrm{mL}-1)$ and visualized and photographed under UV light.

Topoisomerase I-based experiments were performed as described previously.29 Supercoiled pBluescript DNA, obtained as described above, was treated with topoisomerase I in the absence or presence of increasing concentrations of compound $2 \mathrm{c}$. Assay mixtures contained supercoiled pBluescript DNA $(0.8$ $\mu \mathrm{g}$ ), calf thymus topoisomerase I (3 units), and complex $2 \mathrm{c}(0-100 \mu \mathrm{M})$ in $20 \mu \mathrm{L}$ of Tris-HCl buffer ( $\mathrm{pH}$ 7.5) containing $175 \mathrm{mM} \mathrm{KCl}, 5 \mathrm{mM} \mathrm{MgCl}$, and $0.1 \mathrm{mM}$ EDTA. Ethidium bromide $(10 \mu \mathrm{M})$ was used as a control of intercalating agents. Reactions were incubated for $30 \mathrm{~min}$ at $37^{\circ} \mathrm{C}$ and stopped by the addition of $2 \mu \mathrm{L}$ of agarose gel loading buffer. Samples were then subjected to electrophoresis and DNA bands stained with ethidium bromide as described above. 


\section{AUTHOR INFORMATION}

514

515 Corresponding Author

516 *Phone: +34 934039131. Fax: +34 934907725. E-mail: margarita.crespo@qi.ub.es (M. Crespo).

517 *E-mail: quirantese@ub.edu (J. Quirante)..

518

$519 \quad$ Notes

520 The authors declare no competing financial interests.

521 


\section{ACKNOWLEDGMENTS}

523

524 We are grateful to the Ministerio de Ciencia y Tecnología for financial support (Grants CTQ2009-

525 11501/BQU and SAF2011-25726), to the AGAUR, Generalitat de Catalunya (Grants 2009-SGR-1111, 526 2009-SGR-1308, and 2009 CTP 0026), and to the Icrea Academia award 2010 (to M. Cascante). 


\section{REFERENCES}

(1) (a) Cisplatin: Chemistry and Biochemistry of a Leading Anticancer Drug; Lippert, B., Ed.; Verlag Helvetica Chimica Acta: Zurich, 1999. (b) Wheate, N. J.; Walker, S.; Craig, G. E.; Oun, R. Dalton Trans. 2010, 39, 8113.

(2) (a) Tsang, R. Y.; Al-Fayea, T.; Au, H. Drug Safety 2009, 32, 1109. (b) Sullivan, M. J. Cancer $2009,115,5623$.

(3) (a) Köberle, B.; Tomicic, M. T.; Usanova, S.; Kaina, B. Biochim. Biophys. Acta Rev. Cancer 2010, 1806, 172. (b) Shen, D. W.; Hall, L. M.; Gottesman, M. Pharmacol. Rev. 2012, 64, 706-721. (c) Heffeter, P.; Jungwirth, U.; Jakupec, M.; Hartinger, C.; Galanski, M.; Elbling, L.; Micksche, M.; Keppler, B. K.; Berger, W. Drug Resist. Updates 2008, 11, 1.

(4) (a) Noffke, A. L.; Habtemariam, A.; Pizarro, A. M.; Sadler, P. J. Chem. Commun. 2012, 48, 5219. (b) Barry, N. P. E.; Sadler, P. J. Chem. Commun. 2013, 45, 5106. (c) Sava, G.; Bergamo, A.; Dyson, P. J. Dalton Trans. 2011, 40, 9069. (d) van Rijt, S. H.; Sadler, P. J. Drug Discovery Today 2009, 14, 1089. (e) Harper, B. W.; Krause-Heuer, A. M.; Grant, M. P.; Manohar, M.; Garbutcheon-Singh, K. B.; Aldrich-Wright, J. R. Chem.૯Eur. J. 2010, 16, 7064. (f) Gasser, G.; Ott, I.; Metzler-Nolte, N. J. Med. Chem. 2011, 54, 3. (g) Hartinger, C. G.; Metzler-Nolte, N.; Dyson, P. J. Organometallics 2012, 31, 5677. (h) Olszewski, U.; Hamilton, G. Anti-Cancer Agents Med. Chem. 2010, 10, 293. (i) Wong, E.; Giandomenico, C. M. Chem. Rev. 1999, 99, 2451. (j) Aris, S. M.; Farrell, N. P. Eur. J. Inorg. Chem. 2009, 1293. (k) Klein, A. V.; Hambley, T. W. Chem. Rev. 2009, 109, 4911. (1) Hambley, T. W. Dalton Trans. 2007, 4929. (m) Johnstone, T. C.; Wilson, J. J.; Lippard, S. J. Inorg. Chem. 2013, 52, 1234.

(5) (a) Navarro-Ranninger, C.; López-Solara, I.; González, V. M.; Pérez, J. M.; Alvarez-Valdés, A.; Martín, A.; Raithby, P. R.; Masaguer, J. R.; Alonso, C. Inorg. Chem. 1996, 35, 5181. (b) ElMehasseb, I. M.; Kodaka, M.; Okada, T.; Tomohiro, T.; Okamoto, K.; Okuno, H. J. Inorg. Biochem. 2001, 84, 157. (c) Okada, T.; El-Mehasseb, I. M.; Kodaka, M.; Tomohiro, T.; Okamoto, K.; Okuno, H. J. Med. Chem. 2001, 44, 4661. (d) Edwards, G. L.; Black, D. St.C.; Deacon, G. B.; Wakelin, L. P. G. Can. J. Chem. 2005, 83, 969. (e) Edwards, G. L.; Black, D. 
St.C.; Deacon, G. B.; Wakelin, L. P. G. Can. J. Chem. 2005, 83, 980. (f) Ruiz, J.; Lorenzo, J.;

Sanglas, L.; Cutillas, N.; Vicente, C.; Villa, M. D.; Avilés, F. X.; López, G.; Moreno, V.; Pérez, J.; Bautista, D. Inorg. Chem. 2006, 45, 6347. (g) Samouei, H.; Rashidi, M.; Heinemann, F. W. J. Inorg. Biochem. 2013, 118, 1. (i) Albert, J.; Bosque, R.; Crespo, M.; Granell, J.; López, C.; Cortés, R.; González, A.; Quirante, J.; Calvis, C.; Messeguer, R.; Baldomà, L.; Badia, J.; Cascante, M. Bioorg. Med. Chem. 2013, 21, 4210. (j) Ruiz, J.; Vicente, C.; De Haro, C.; Espinosa, A. Inorg. Chem. 2011, 50, 2151. (k) Ruiz, J.; Rodríguez, V.; Cutillas, N.; Espinosa, A.; Hannon, M. J. J. Inorg. Biochem. 2011, 105, 525. (1) Ruiz, J.; Cutillas, N.; Vicente, C.; Villa, M. D.; López, G.; Lorenzo, J.; Avilés, F. X.; Moreno, V.; Bautista, D. Inorg. Chem. 2005, 44, 7365. (m) Ruiz, J.; Rodríguez, V.; Cutillas, N.; López, G.; Bautista, D. Inorg. Chem. 2008, 47, 10025. (n) Ruiz, J.; Lorenzo, J.; Vicente, C.; López, G.; López de Luzuriaga, J. M.; Monge, M.;

Avilés, F. X.; Bautista, D.; Moreno, V.; Laguna, A. Inorg. Chem. 2008, 47, 6990. (o) Cutillas, N.; Martínez, A.; Yellol, G. S.; Rodríguez, V.; Zamora, A.; Pedreño, M.; Donaire, A.; Janiak, C.; Ruiz, J. Inorg. Chem. 2013, 52, 13529.

(a) Cortés, R.; Crespo, M.; Davin, L.; Martín, R.; Quirante, J.; Ruiz, D.; Messeguer, R.; Calvis, C.; Baldomà, L.; Badia, J.; Font-Bardía, M.; Calvet, T.; Cascante, M. Eur. J. Med. Chem. 2012, 54, 557. (b) Ma, D.-L.; Che, C.-M. Chem.-Eur. J. 2003, 9, 6133. (c) Wang, P.; Leung, C.-H.; Ma, D.-L.; Sun, R. W.-Y.; Yan, S.-C.; Chen, Q.-S.; Che, C.-M. Angew. Chem., Int. Ed. 2011, 50, 2554. (d) Quirante, J.; Ruiz, D.; González, A.; López, C.; Cascante, M.; Cortés, R.; Messeguer, R.; Calvis, C.; Baldomà, L.; Pascual, A.; Guérardel, Y.; Pradines, B.; Font-Bardia, M.; Calvet, T.; Biot, C. J. Inorg. Biochem. 2011, 105, 1720. (e) Chellan, P.; Land, K. M.; Shokar, A.; Au, A.; An, S. H.; Clavel, C. M.; Dyson, P. J.; de Kock, C.; Smith, P. J.; Chibale, K.; Smith, G. S. Organometallics 2012, 31, 5791. 
Keck, M. V.; Lippard, S. J. J. Am. Chem. Soc. 1992, 114, 3386.

585

(8)

(a) Hall, M. D.; Mellor, H. R.; Callaghan, R.; Hambley, T. W. J. Med. Chem. 2007, 50, 3403.

586

(b) Choy, H.; Park, C.; Yao, M. Clin. Cancer Res. 2008, 14, 1633. (c) Zhang, J. Z.; Wexselblatt,

E.; Hambley, T. W.; Gibson, D. Chem. Commun. 2012, 48, 847. (d) Varbanov, H.; Valiahdi, S. M.; Jakupec, M. A.; Galanski, M.; Keppler, B. K. Dalton Trans. 2012, 41, 14404-14415. (e) Wexselblatt, E.; Gibson, D. J. Inorg. Biochem. 2012, 117, 220-229. (f) Sinisi, M.; Intini, F. P.; Natile, G. Inorg. Chem. 2012, 51, 9694. (g) Cubo, L.; Hambley, T. W.; Miguel, P. J. S.; Carnero, A.; Navarro-Ranninger, C.; Quiroga, A. G. Dalton Trans. 2011, 40, 344. (h) Hoffmeister, B. R.; Adib-Razavi, M. S.; Jakupec, M. A.; Galanski, M.; Keppler, B. K. Chem. Biodiversity 2012, 9, 1840. (i) Chin, C. F.; Tian, Q.; Setyawati, M. I.; Fang, W.; Tan, E. S. Q.; Leong, D. T.; Ang, W. H. J. Med. Chem. 2012, 55, 7571. (j) Ellis, L. T.; Harnbley, T. W. Aust. J. Chem. 2006, 48, 793. (k) Guo, S.-X.; Mason, D. N.; Turland, S. A; Lawrenz, E. T.; Kelly, L. 599 600

(13) Bernhardt, P. V.; Calvet, T.; Crespo, M.; Font-Bardia, M.; Jansat, S.; Martínez, M. Inorg. Chem. 2013, 52, 474 . 
(14) (a) Klein, A.; Lüning, A.; Ott, I.; Hamel, L.; Neugebauer, M.; Butsch, K.; Lingen, V.; Heinrich, F.; Elmas, S. J. Organomet. Chem. 2010, 695, 1898. (b) Cullinane, C.; Deacon, G. B.; Drago, P. R.; Hambley, T. W.; Nelson, K. T.; Webster, L. K. J. Inorg. Biochem. 2002, 89, 293. (c) Hambley, T. W.; Battle, A. R.; Deacon, G. B.; Lawrenz, E. T.; Fallon, G. D.; Gatehouse, B. M.; Webster, L. K.; Rainone, S. J. Inorg. Biochem. 1999, 77, 3.

(15) Espinet, P.; Albéniz, A. C.; Casares, J. A.; Martínez-Ilarduya, J. M. Coord. Chem. Rev. 2008, $252,2180$.

(16) Crespo, M. Organometallics 2012, 31, 1213.

(17) Müller, K.; Faeh, C.; Diederich, F. Science 2007, 317, 1881.

(18) Shafaatian, B.; Akbari, A.; Nabavizadeh, S. M.; Heinemann, F. W.; Rashidi, M. Dalton Trans. $2007,4715$.

(19) Casado Lacabra, M. A.; Canty, A. J.; Lutz, M.; Patel, J.; Spek, A. L.; Sun, H.; van Koten, G. Inorg. Chim. Acta 2002, 327, 15.

(20) (a) Anderson, C. M.; Crespo, M.; Jennings, M. C.; Lough, A. J.; Ferguson, G.; Puddephatt, R. J. Organometallics 1991, 10, 2672. (b) Anderson, C. M.; Crespo, M.; Ferguson, G.; Lough, A. J.; Puddephatt, R. J. Organometallics 1992, 11, 1177.

(21) Janiak, C. J. Chem. Soc., Dalton Trans. 2000, 3885.

(22) Lutnaes, B. F.; Luthe, G.; Brinkman, U. A. Th.; Johansen, J. E.; Krane, J. Magn. Reson. Chem. $2005,43,588$.

(23) (a) Gracia, C.; Marco, G.; Navarro, R.; Romero, P.; Soler, T.; Urriolabeitia, E. P. Organometallics 2003, 22, 4910. (b) Crosby, S. H.; Clarkson, G. J.; Deeth, R. J; Rourke, J. P. Organometallics 2010, 29, 1966. (c) Mamtora, J.; Crosby, S. H.; Newman, C. P.; Clarkson, G. J.; Rourke, J. P. Organometallics 2008, 27, 5559.

(24) Priqueler, J. R. L.; Butler, I. S.; Rochon, F. D. Appl. Spectrosc. Rev. 2006, 41, 185.

(25) (a) Font-Bardia, M.; Gallego, C.; Martinez, M.; Solans, X. Organometallics 2002, 21, 3305. (b) Gallego, C.; Martinez, M.; Safont, V. S. Organometallics 2007, 26, 527. (c) Crespo, M.; FontBardia, M.; Solans, X. J. Organomet. Chem. 2006, 691, 1897. 
(26) (a) Minghetti, G.; Stoccoro, S.; Cinellu, M. A.; Soro, B.; Zucca, A. Organometallics 2003, 22, 4770. (b) Zucca, A.; Doppiu, A.; Cinellu, M. A.; Stoccoro, S.; Minghetti, G.; Manassero, M. Organometallics 2002, 21, 783. (c) Yagyu, T.; Ohashi, J.; Maeda, M. Organometallics 2007, 26, 2383. (d) Sarkar, B.; Schurr, T.; Hartenbach, I.; Schleid, T.; Fiedler, J.; Kaim, W. J. Organomet. Chem. 2008, 693, 1703. (e) Zucca, A.; Petretto, G. L.; Stoccoro, S.; Cinellu, M. A.; Minghetti, G.; Manassero, M.; Manassero, C.; Male, L.; Albinati, A. Organometallics 2006, 25, 2253. (f) Nabavizadeh, S. M.; Amini, H.; Shahsavari, H. R.; Namdar, M.; Rashidi, M.; Kia, R.; Hemmateenejad, B.; Nekoeinia, M.; Ariafard, A.; Hosseini, F. N.; Gharavi, A.; Khalafi-Nezhad, A.; Sharbati, M. T.; Panahi, F. Organometallics 2011, 30, 1466. (g) Nabavizadeh, S. M.; Haghighi, M. G.; Esmaeilbeig, A. R.; Raoof, F.; Mandegani, Z.; Jamali, S.; Rashidi, M.; Puddephatt, R. J. Organometallics 2010, 29, 4893. (h) Nabavizadeh, S. M.; Shahsavari, H.; Namdar, M.; Rashidi, M.; Puddephatt, R. J. J. Organomet. Chem. 2011, 696, 3564.

(27) Calvet, T.; Crespo, M.; Font-Bardia, M.; Gómez, K.; González,

G.; Martínez, M. Organometallics 2009, 28, 5096.

(28) Snyder, R. D.; McNulty, J.; Zairov, G.; Ewing, D. E.; Hendry, L. B. Mutat. Res., Fundam. Mol. Mech. Mutagen. 2005, 1-2, 88.

(29) Palchaudhuri, R.; Hergenrother, P. J. Curr. Opin. Biotechnol. 2007, 18, 497.

(30) Sappal, D. S.; McClendon, A. K.; Fleming, J. A.; Thoroddsen, V.; Connolly, K.; Reimer, C.; Blackman, R. K.; Bulawa, C. E.; Osheroff, N.; Charlton, P.; Rudolph-Owen, L. A. Mol. Cancer Ther. 2004, 3, 47.

(31) Sheldrick, G. M. Acta Crystallogr. 2008, A64, 112-122.

(32) Favier, I.; Gómez, M.; Granell, J.; Martínez, M.; Solans, X.; Font-Bardia, M. Dalton Trans. $2005,123$.

(33) De Crisci, A. G.; Lough, A. J.; Multani, K.; Fekl, U. Organometallics 2008, 27, 1765.

(34) Mosmann, T. J. Immunol. Methods 1983, 65, 55.

(35) Matito, C.; Mastorakou, F.; Centelles, J. J.; Torres, J. L.; Cascante, M. Eur. J. Nutr. 2003, 42, 42. 
664 (36) Abdullah, A.; Huq, F.; Chowdhury, A.; Tayyem, H.; Beale, P.; Fisher, K. BMC Chem. Biol.

665 $2006,6,3$.

666 
Figure 1. Molecular structure of compound A. Hydrogen atoms have been omitted for clarity. Selected

671

672

673

674

675

676

677

678

679

680

681

682

683

684

685

686

687

688

689

690

691

692

693

694

695

696

697

698

699

700

701

702

703

bond lengths $(\AA)$ and angles (deg) with estimated standard deviations: $\operatorname{Pt}(1)-C(7): 2.006(8) ; \operatorname{Pt}(1)-C(1)$ : 2.015(7); Pt(1)-S(2): 2.3504(16); Pt(1)-S(1): 2,3581(19); Pt(2)-C(19): 2,029(6); Pt(2)-C(13): 2,039(7); $\mathrm{Pt}(2)-\mathrm{S}(2): 2.3545(18) ; \mathrm{Pt}(2)-\mathrm{S}(1): 2.3705(16) ; \mathrm{C}(7)-\mathrm{Pt}(1)-\mathrm{C}(1): 89.8(3) ; \mathrm{C}(7)-\mathrm{Pt}(1)-\mathrm{S}(2): 96.11(11)$; $\mathrm{C}(1)-\mathrm{Pt}(1)-\mathrm{S}(1)$ : 93.6(2); $\mathrm{S}(2)-\mathrm{Pt}(1)-\mathrm{S}(1): 80.45(6) ; \mathrm{C}(19)-\mathrm{Pt}(2)-\mathrm{C}(13)$ : 91.2(3); C(19)-Pt(2)-S(2): 94.1(2); C(13)-Pt(2)-S(1): 94.53(18); S(2)-Pt(2)-S(1): 80.11(6).

Scheme 1. Synthesis of Coordination and Cyclometalated Platinum Compounds from Precursor Aa

Scheme 2. Isomerization and Reactivity of Compound $2 b$

Figure 2. Molecular structure of compound 2d. Hydrogen atoms have been omitted for clarity. Selected bond lengths $(\AA)$ and angles (deg) with estimated standard deviations: $\mathrm{Pt}-\mathrm{C}(7)$ : 2.007(6); $\mathrm{Pt}-\mathrm{C}(1)$ : 2.025(6); Pt-N(1): 2.096(4); Pt-N(2): 2,214(5); N(1)-C(15): 1.260(7); N(1)-C(14): 1.501(8); $\mathrm{N}(2)-\mathrm{C}(13): 1.464(8) ; \mathrm{C}(13)-\mathrm{C}(14): 1.525(9) ; \mathrm{C}(7)-\mathrm{Pt}-\mathrm{C}(1)$ : 88.4(2); C(7)-Pt-N(1): 96.0(2); $\mathrm{C}(1)-\mathrm{Pt}-\mathrm{N}(2): 94.9(2) ; \mathrm{N}(1)-\mathrm{Pt}-\mathrm{N}(2): 80.62(18)$.

Figure 3. Molecular structure of compound 4a. Hydrogen atoms have been omitted for clarity. Selected bond lengths $(\AA)$ and angles (deg) with estimated standard deviations: $\mathrm{Pt}-\mathrm{C}(1)$ : 2.001(6); $\mathrm{Pt}-\mathrm{C}(12)$ : 2.051(6); Pt-C(18): 2.060(7); Pt-Br: 2.5919(6); Pt-N(1): 2.082(5); Pt-N(2): 2,337(5); N(1)-C(7): 1.272(8); $\mathrm{N}(1)-\mathrm{C}(8): 1.455(8) ; \mathrm{N}(2)-\mathrm{C}(9): 1.506(8) ; \mathrm{C}(8)-\mathrm{C}(9): 1.515(9) ; \mathrm{C}(1)-\mathrm{Pt}-\mathrm{C}(12): 95.6(2) ;$ $\mathrm{C}(1)-\mathrm{Pt}-\mathrm{N}(1): 81.1(2) ; \mathrm{C}(12)-\mathrm{Pt}-\mathrm{N}(2): 104.9(2) ; \mathrm{N}(1)-\mathrm{Pt}-\mathrm{N}(2): 78.6(2) ; \mathrm{C}(1)-\mathrm{Pt}-\mathrm{C}(18): 92.9(2)$; C(12)-Pt-C(18): 87.3(2); C(18)-Pt-N(1): 90.7(2); C(18)-Pt-N(2): 93.0(2); C(1)-Pt-Br: 84.76(17); C(12)-Pt-Br: 91.54(17); N(1)-Pt-Br: 90.29(15); N(2)-Pt-Br: 89.66(13).

Figure 4. Molecular structure of compound $5 \mathrm{~d}$. The disordered moiety and the hydrogen atoms have been omitted for clarity. Selected bond lengths $(\AA)$ and angles (deg) with estimated standard deviations: $\mathrm{Pt}(1)-\mathrm{C}(2): 1.986(7) ; \mathrm{Pt}(1)-\mathrm{N}(1): 1.992(7) ; \mathrm{Pt}(1)-\mathrm{N}(2): 2.183(6) ; \mathrm{Pt}(1)-\mathrm{Cl}(1): 2.293(2) ; \mathrm{C}(1)-\mathrm{C}(2)$ : 1.407(8); $\mathrm{C}(1)-\mathrm{C}(7): 1.513(8) ; \mathrm{N}(1)-\mathrm{C}(13): 1.272(11) ; \mathrm{N}(1)-\mathrm{C}(14): 1.483(11) ; \mathrm{N}(2)-\mathrm{C}(15): 1.505(13)$; $\mathrm{C}(7)-\mathrm{C}(8): 1.406(11) ; \mathrm{C}(8)-\mathrm{C}(13): 1.463(11) ; \mathrm{C}(14)-\mathrm{C}(15): 1.505(14) ; \mathrm{C}(2)-\mathrm{Pt}(1)-\mathrm{N}(1)$ : 92.1(3); $\mathrm{N}(1)-\operatorname{Pt}(1)-\mathrm{N}(2): 82.9(3) ; \mathrm{C}(2)-\operatorname{Pt}(1)-\mathrm{Cl}(1): 93.1(2) ; \mathrm{N}(2)-\operatorname{Pt}(1)-\mathrm{Cl}(1): 92.0(2)$.

Scheme 3. Formation of Compound $5 \mathrm{~d}$ 
704 Figure 5. Inhibition of cell growth proliferation in the A549 human lung cancer cell line, after $72 \mathrm{~h}$ of 705 exposure to coordination compounds (2b-2d) (top), cyclometalated compounds (4a, 5b, 5d) (bottom), 706 and cisplatin.

707

708 Figure 6. Interaction of pBluescript SK+ plasmid DNA $(0.8 \mu \mathrm{g})$ with increasing concentrations of 709 compounds 2, 4, and 5, cisplatin, and ethidium bromide. Lane 1: DNA only. Lane 2: $2.5 \mu \mathrm{M}$. Lane 3: 5 $710 \mu \mathrm{M}$. Lane 4: $10 \mu \mathrm{M}$. Lane 5: $25 \mu \mathrm{M}$. Lane 6: $50 \mu \mathrm{M}$. Lane 7: $100 \mu \mathrm{M}$. Lane 8: $200 \mu \mathrm{M}$. ccc $=$ 711 supercoiled closed circular DNA; oc = open circular DNA.

712

713 Figure 7. Analysis of $2 \mathrm{c}$ as a putative DNA intercalator or topoisomerase I inhibitor. Conversion of 714 supercoiled pBluescript plasmid DNA $(0.8 \mu \mathrm{g})$ to relaxed DNA by the action of topoisomerase I (3 715 units) in the absence or in the presence of increasing amounts of compound $2 \mathrm{c}$ was analyzed by agarose 716 gel stained with ethidium bromide $(\mathrm{EtBr})$. Also shown are the negative and positive intercalator 717 controls, etoposide (Etop, $100 \mu \mathrm{M}$ ) and ethidium bromide (EtBr, $10 \mu \mathrm{M})$. Lanes 1, DNA only, lane 2, 0 $718 \mu \mathrm{M}$ compound; lanes 3, $10 \mu \mathrm{M}$; lane 4, $25 \mu \mathrm{M}$, lane 5, $50 \mu \mathrm{M}$; lanes 6, $100 \mu \mathrm{M}$. Except for lane 1, all the 719 lanes included topoisomerase I. $\mathrm{ccc}=$ supercoiled closed circular DNA form; oc $=$ open circular DNA 720 form. 


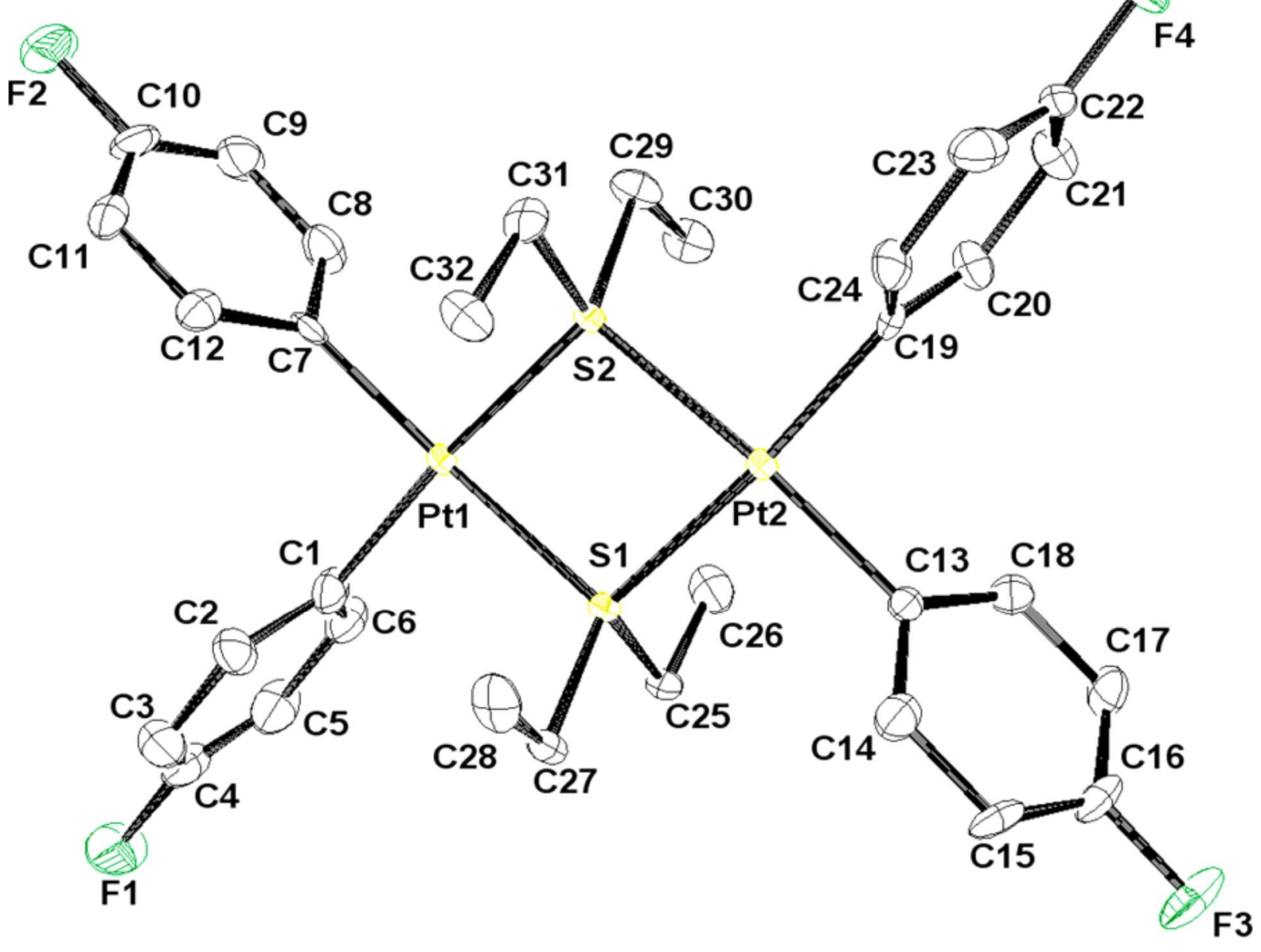

726 

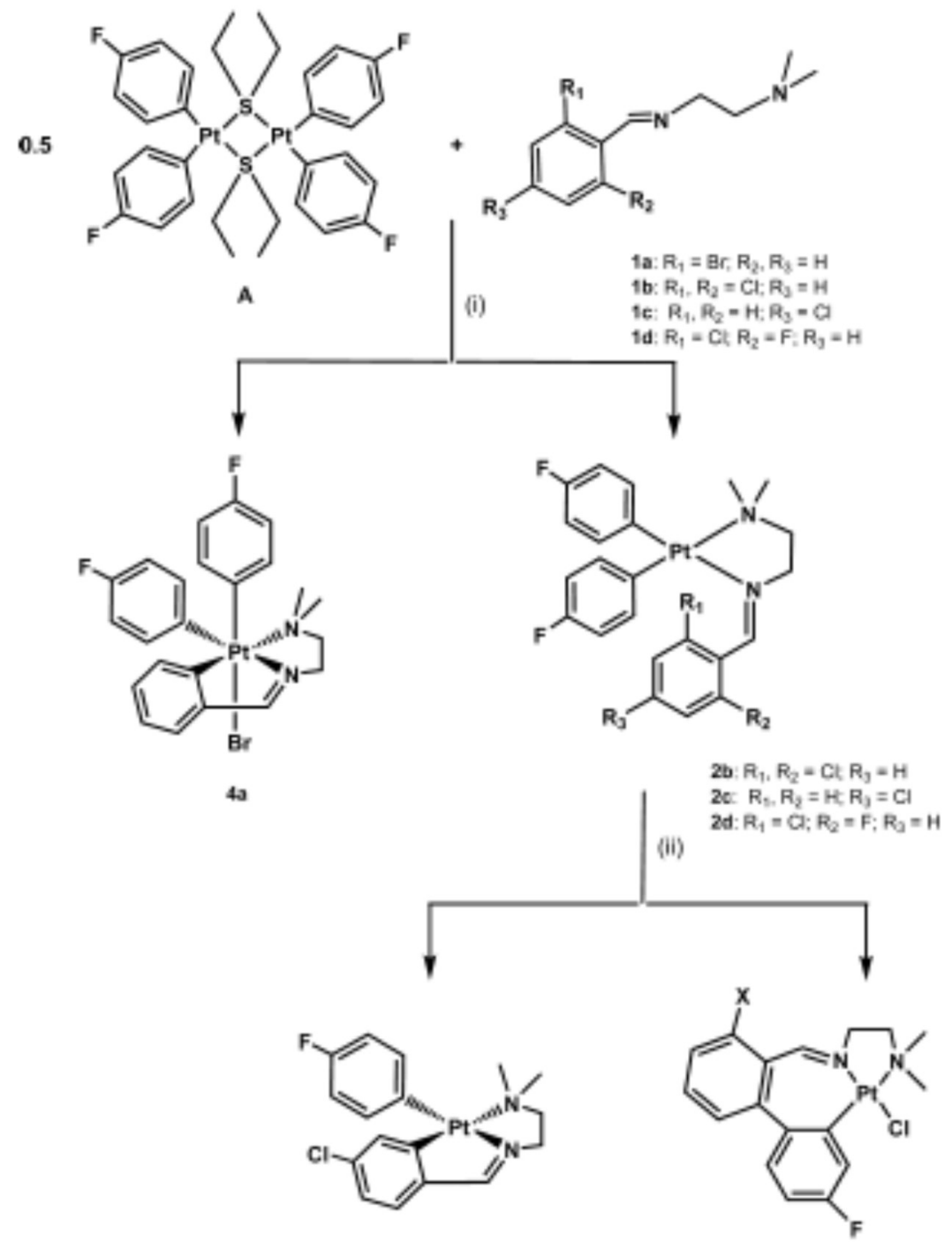
SCHEME 2

733

734

735<smiles></smiles>

25)<smiles>[3H][3H]</smiles>

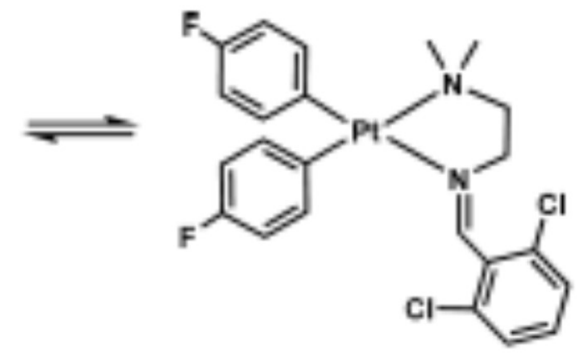

$2 b-4$

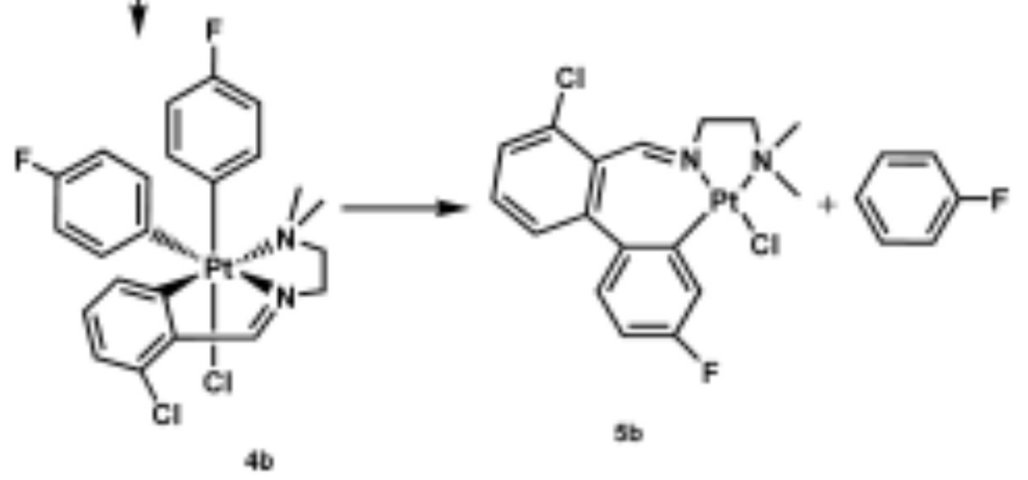

736 


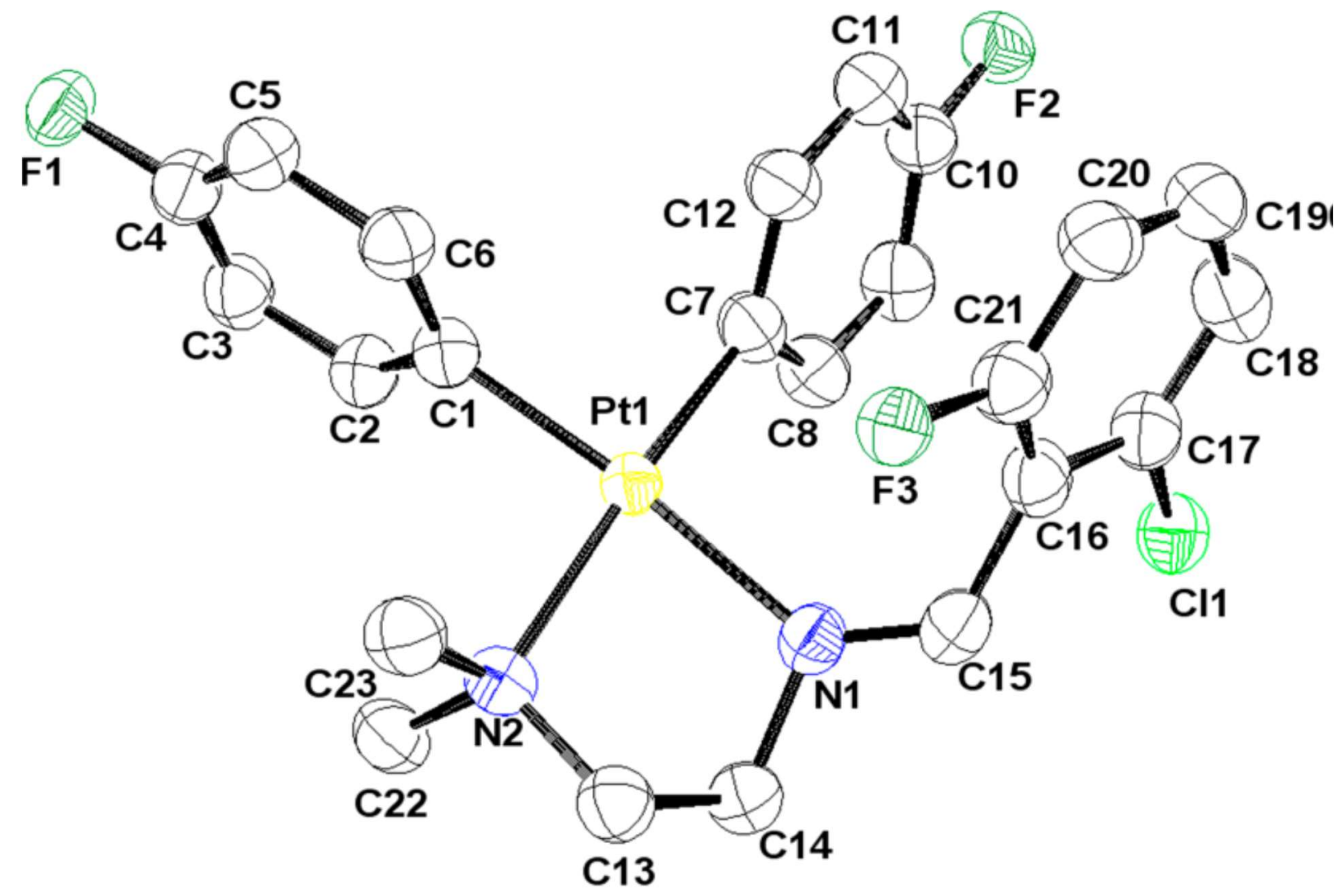




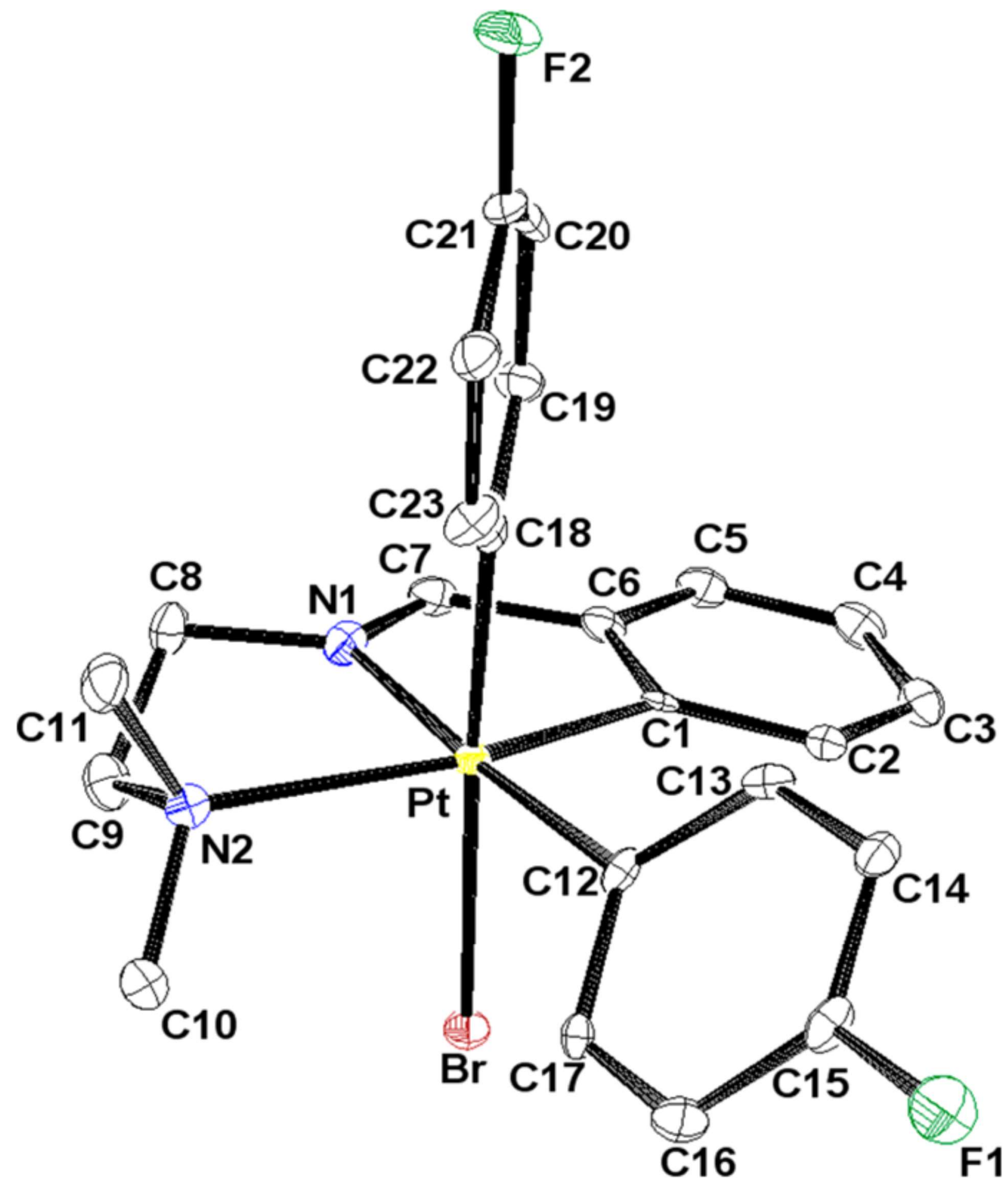




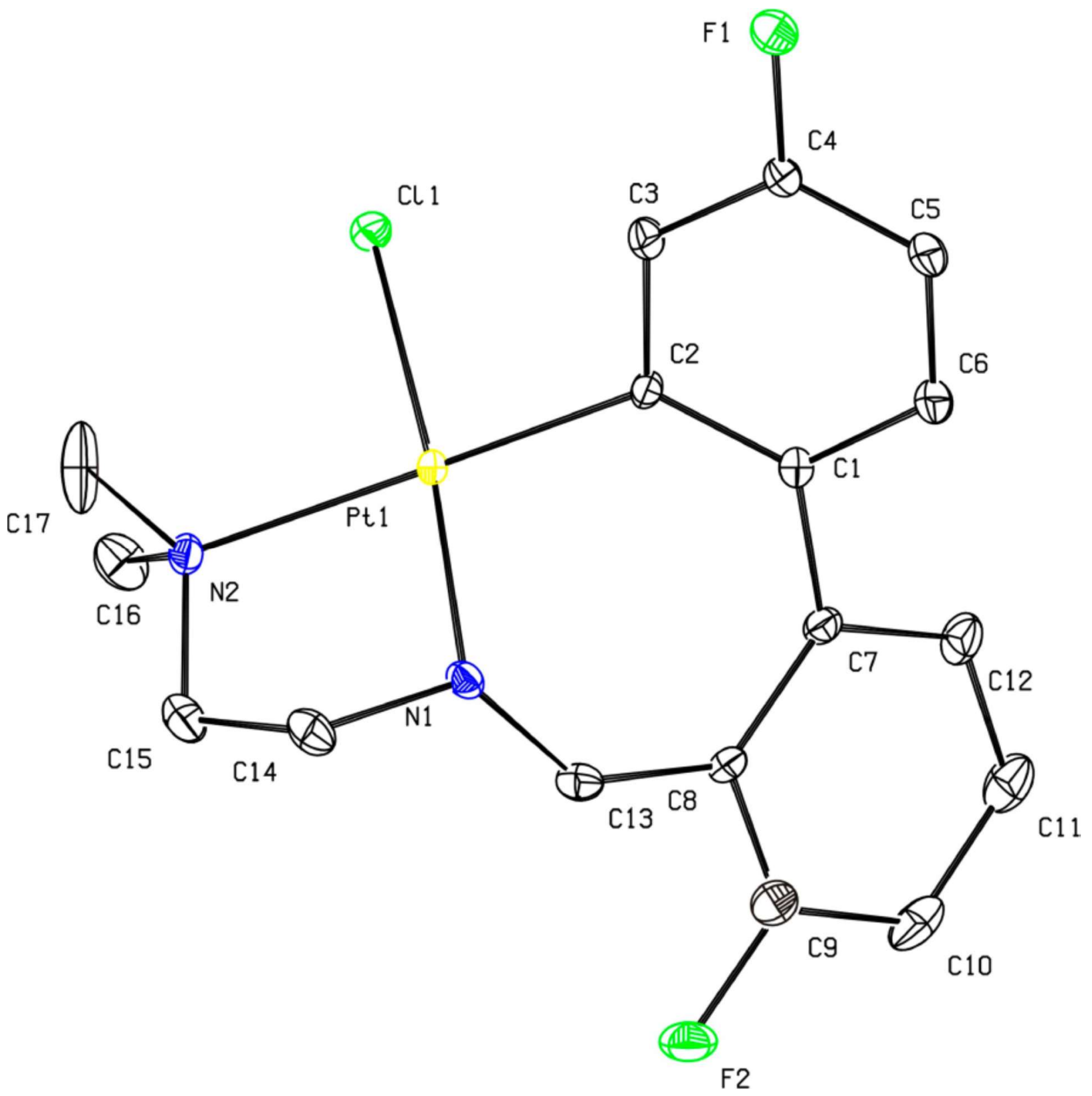


SCHEME 3

755

756
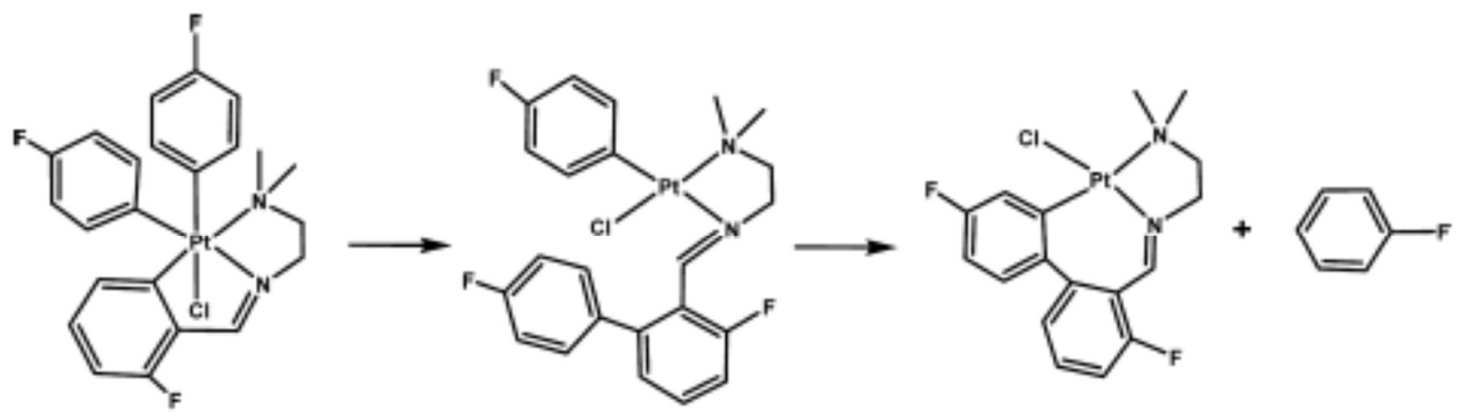

757

$5 d$

758 


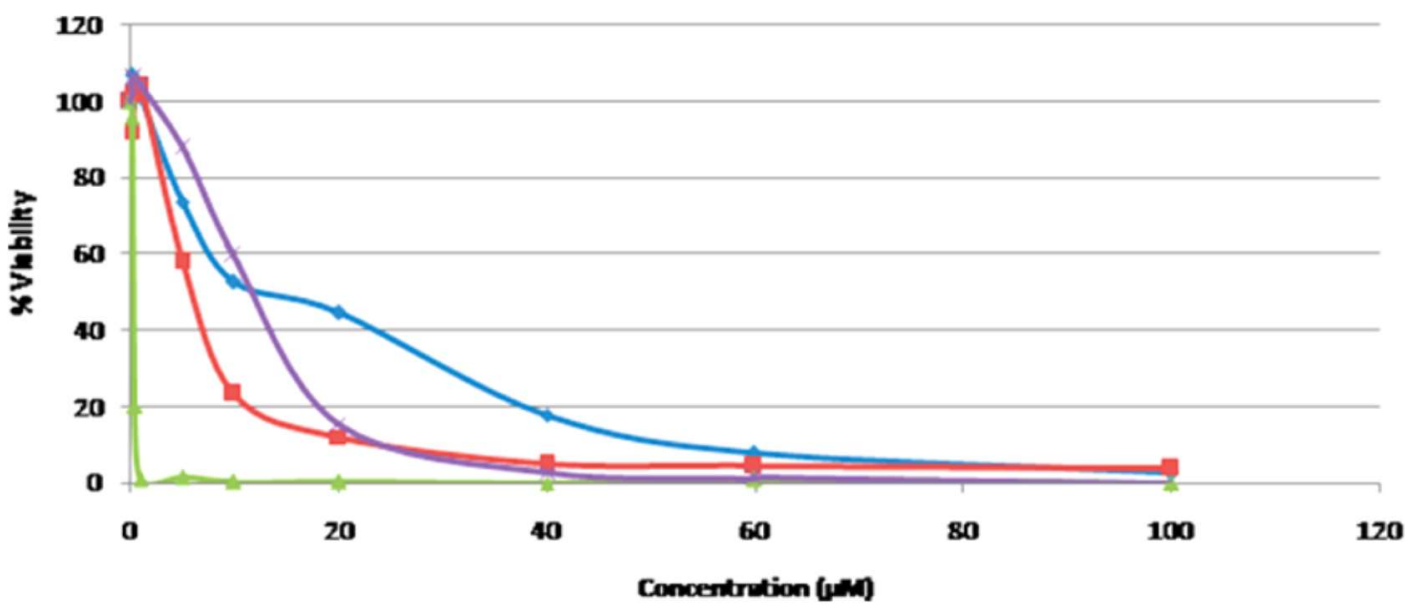

$\multimap$ Coplatin

$-\mathbf{z b}$

$-2 c$

$-2 d$
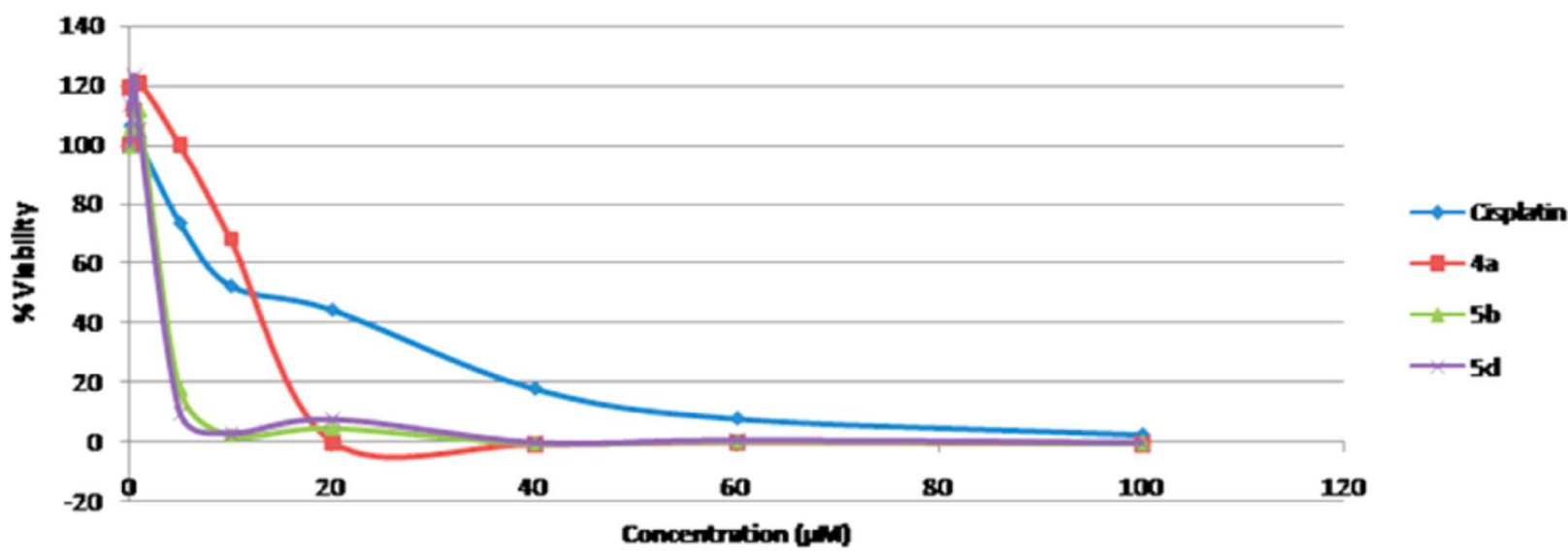

762 

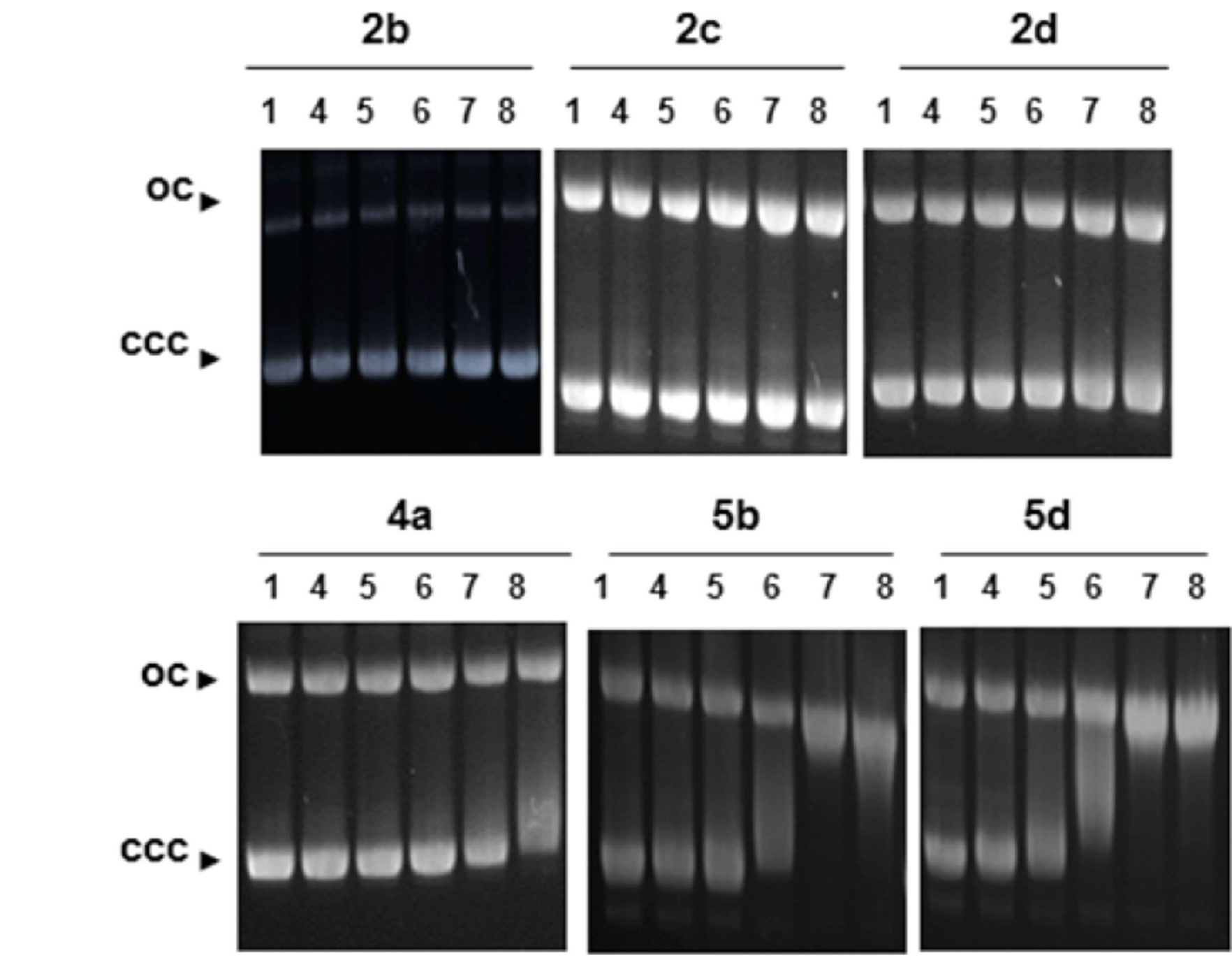

2d

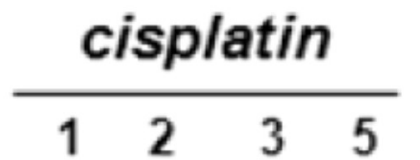

EtB

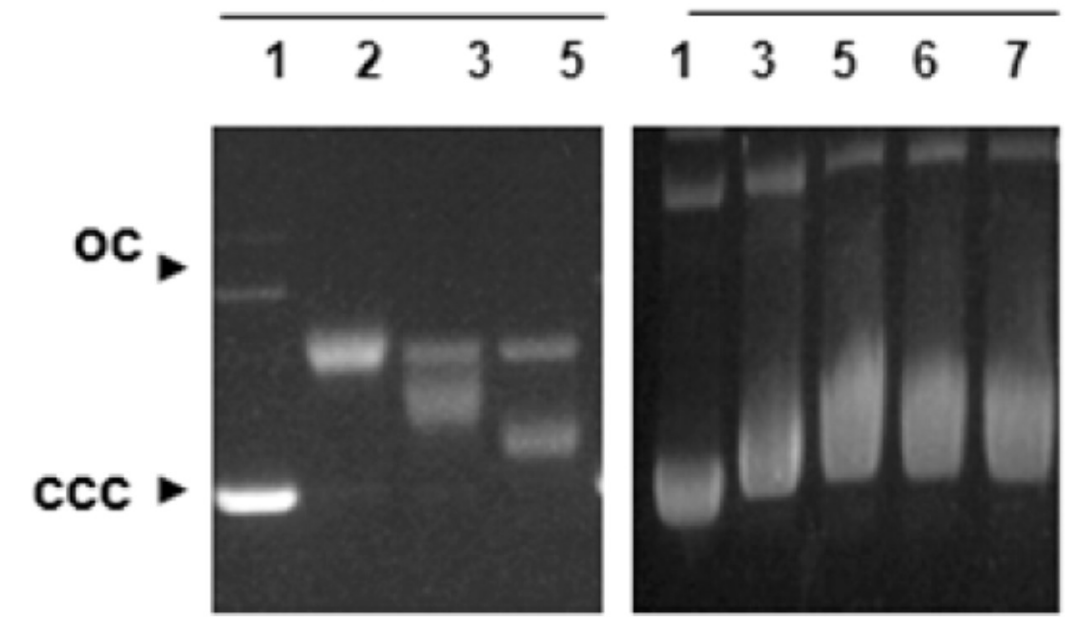




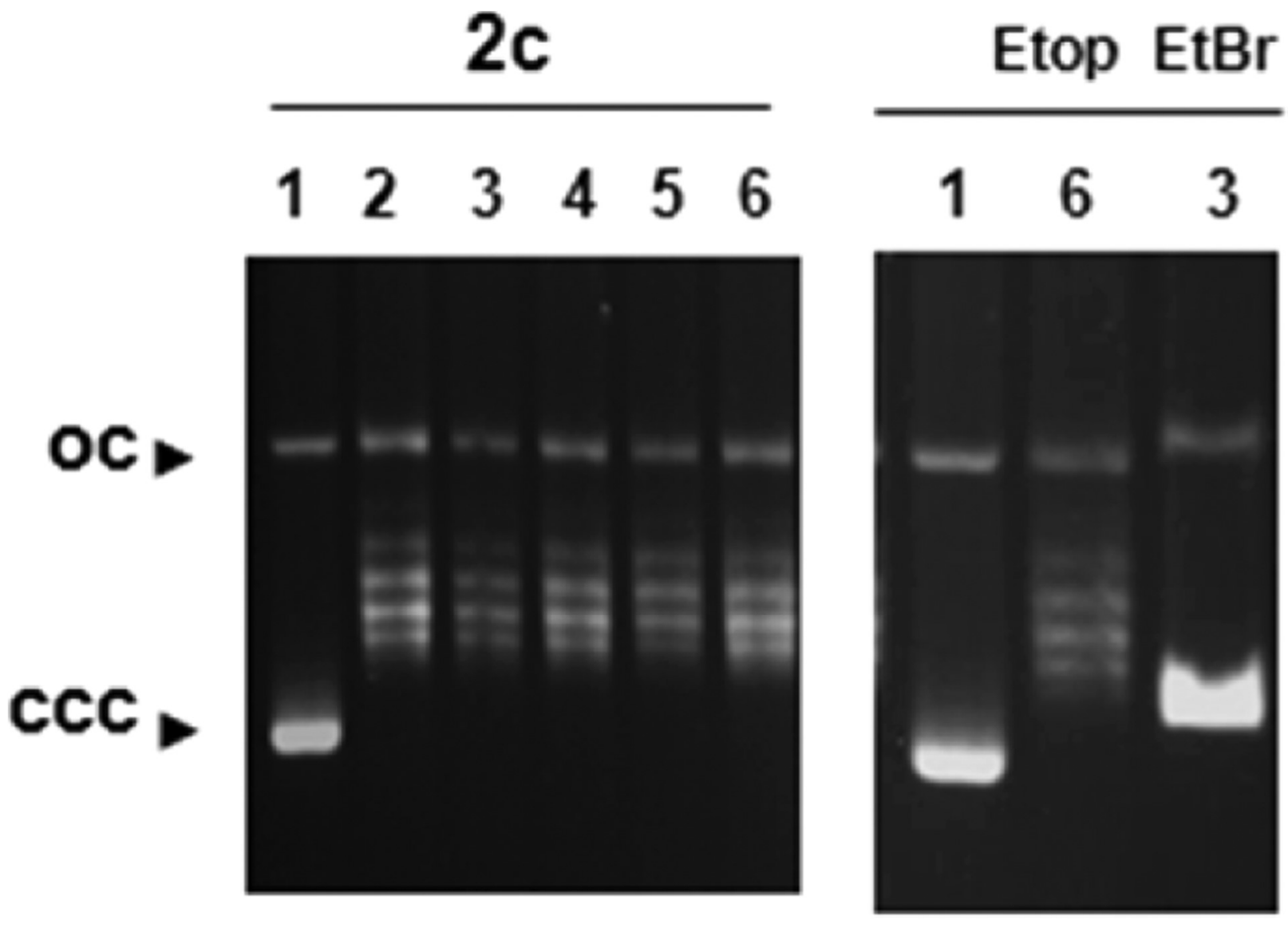


774 Table 1. Cytotoxic activities on the A549 Lung Human Cancer Cell Line for Studied Compounds and 775 Cisplatin

\begin{tabular}{|c|c|}
\hline compound & $\mathrm{IC}_{\phi \theta}(\mu \mathrm{M})^{-}$ \\
\hline la & $>100$ \\
\hline lb & $>100$ \\
\hline $1 c$ & $>100$ \\
\hline $1 d$ & $>100$ \\
\hline $2 b$ & $6.5 \pm 20$ \\
\hline $2 c$ & $0.3 \pm 0.1$ \\
\hline $2 d$ & $121=0.8$ \\
\hline $4 a$ & $11.6 \pm 22$ \\
\hline $5 b$ & $2.8 \pm 0.5$ \\
\hline sd & $2.5 \pm 0.1$ \\
\hline claphtin & $14.1 \pm 1.3$ \\
\hline
\end{tabular}

